\title{
28. QUATERNARY PLANKTONIC FORAMINIFERS OF THE SOUTHWESTERN ATLANTIC (RIO GRANDE RISE) DEEP SEA DRILLING PROJECT LEG 72 ${ }^{1}$
}

\author{
C. Pujol and J. Duprat, Université de Bordeaux I, Départment de Géologie et Océanographie, Avenue des Facultés \\ 33405 Talence Cedex, France
}

\begin{abstract}
Quaternary sediments were recovered at all four Sites at Leg 72. Planktonic foraminifers were abundant and well preserved, especially in the holes shielded from Antarctic Bottom Water (AABW) influence. The fauna belonged to the subtropical province marked by Globigerinoides ruber and to a lesser extent by Globorotalia inflata. Thirty planktonic foraminiferal species were distinguished, and a detailed study of the Site 517 stratigraphy was made.

The Quaternary sequence of the Rio Grande Rise was subdivided slightly differently from the Bolli and Premoli Silva (1973) pattern. Five subzones were identified but some difficulties arose when a precise correlation became necessary in the subzones of the tropical provinces. Correlations could nevertheless be made, particularly with respect to the earliest Quaternary.

Quaternary faunal data have been dated by isotopic stratigraphy (Vergnaud Grazzini et al., this volume) and partially contradict results previously published for this part of the Atlantic (Williams and Ledbetter, 1979).

By studying the occurrence of planktonic foraminifers, we obtained more information about hydrologic variations during the Quaternary sequence of Hole 517; two broad periods were recognized. Finally, we identified the interaction between the Brazil Current and the subtropical convergence.
\end{abstract}

\section{INTRODUCTION}

During the Deep Sea Drilling Project Leg 72, Quaternary sediments were recovered for 4 sites off the Brazilian coast (Fig. 1, Table 1).

These different sites were selected in order to examine a range of paleodepths around the Rio Grande Rise for analysis of changes in paleoenvironments in the southwestern Atlantic. The profile of sites includes Site 516 on the upper part of the Rio Grande Rise (water depth $1313 \mathrm{~m}$ ), Site 517 on the west flank (depth $2963 \mathrm{~m}$ ), Site 518 (depth $3944 \mathrm{~m}$ ), and Site 515 in the Brazil Basin (depth $4250 \mathrm{~m}$ ). The sites are situated within transition zones between major water masses and at the "core"' of North Atlantic Deep Water (NADW) and Antarctic Bottom Water (AABW). Site 516 was positioned between the Antarctic Intermediate Water (AAIW) and NADW, Site 517 in NADW, Site 518 between the NADW and AABW, and finally Site 515 was located in the AABW.

The deep-sea environment, particularly depth and water aggressivity, determines indirectly the degree of dissolution of calcareous deposits and the distribution of biologic remains on the sea floor. The Quaternary sediments recovered in the uppermost lithologic units of these holes were mainly biogenic oozes, with the exception of the dominance of gray brown terrigenous mud at Site 515. In the shallower holes (Sites 516 and 517), planktonic foraminifers are abundant and well preserved. At Site 515, and to a less degree at Site 518, the dissolution of planktonic microfauna is so strong that it is difficult to make any definitive interpretations.

For several reasons, Site 517 was chosen as a reference for analyzing marine Quaternary sediments of Leg

\footnotetext{
${ }^{1}$ Barker, P. F., Carlson, R. L., Johnson, D. A., et al., Init. Repts. DSDP, 72: Washing. ton (U.S. Govt. Printing Office).
}

72. First, this site has the best continuous sedimentary series of about $25 \mathrm{~m}$ length. Secondly, the planktonic foraminifers are abundant and well preserved. Lastly, this site is located in the present NADW (Reid and others, 1977).

The purpose of this study of planktonic foraminifers is to explore the Quaternary sequences of the southwestern Atlantic, in order to determine the biostratigraphy of these series and interpret hydrologic and paleoclimatic factors from Site 517.

\section{BIOSTRATIGRAPHIC INVESTIGATION}

\section{METHODS}

In our standard section (Site 517), a $10-\mathrm{cm}^{3}$ sample was taken every $10 \mathrm{~cm}$. In Sites 515,516 , and 518 , the core catcher and only one sample for each section were examined. These samples were washed, coarse-fraction dried, and separated for planktonic microfaunal analysis. For each level the residue was microsplit and 4 groups of percentages were established: rare $(0-4 \%)$, few $(5-9 \%)$, common $(10-$ $29 \%$ ), and abundant (more than $30 \%$ ).

\section{Planktonic Foraminifers}

Due to the geographic position of the sites, the uppermost foraminiferal assemblages can be attributed to the subtropical province. Nowadays, the dominant living species (Bé, 1977) are: Globigerinoides ruber and to a lesser extent Globigerina bulloides. The same species occur in the superficial sediments (Boltovskoy, 1973), but with a considerable increase in the relative abundance of the transitional species and/or winter subtropical species Globorotalia inflata and Globigerina pachyderma.

The following species of planktonic foraminifers occur in the Quaternary sediments: Candeina nitida, Globigerina bulloides, G. calida, G. digitata, G. eggeri, G. falconensis, $G$. pachyderma left coiling, G. pachyderma right coiling, G. quinqueloba, G. rubescens group, Glo- 


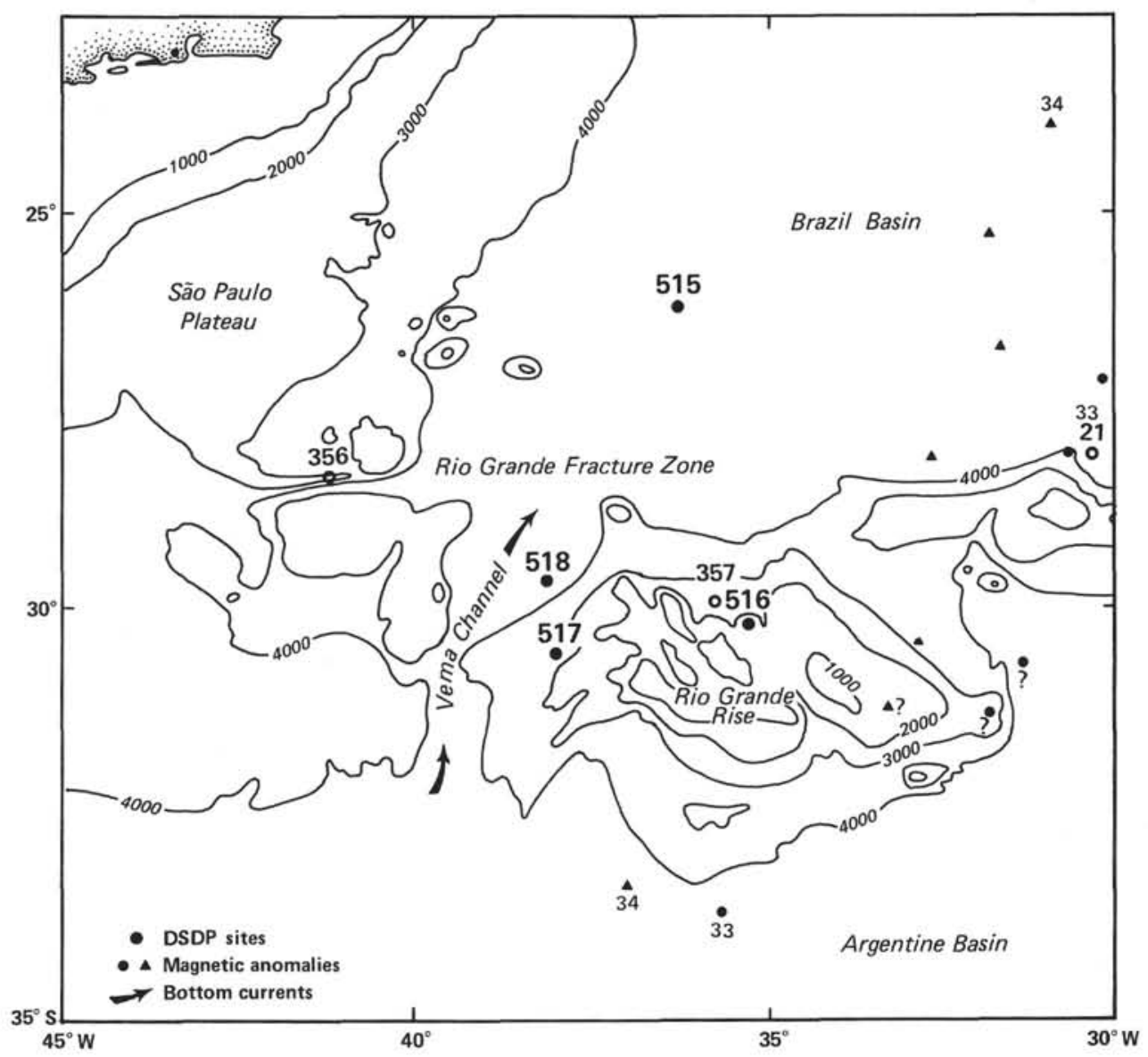

Figure 1. Location map showing Leg 72 sites.

Table 1. Data on the Quaternary sequences of Leg 72 Holes.

\begin{tabular}{lccccr}
\hline Holes & Latitude (S) & Longitude (W) & $\begin{array}{c}\text { Water depth } \\
(\mathrm{m})\end{array}$ & $\begin{array}{c}\text { Drilled in } \\
\text { Quaternary }(\mathrm{m})\end{array}$ & $\begin{array}{c}\text { No. of } \\
\text { samples } \\
\text { used }\end{array}$ \\
\hline 515 & $26^{\circ} 14^{\prime} 33$ & $36^{\circ} 30^{\prime} 17$ & 4250.4 & 49.0 & 6 \\
$515 \mathrm{~A}$ & $26^{\circ} 14^{\prime} 31$ & $36^{\circ} 30^{\prime} 17$ & 4252.0 & 42.0 & 21 \\
516 & $30^{\circ} 16^{\prime} 58$ & $35^{\circ} 17^{\prime} 11$ & 1313.0 & 7.2 & 11 \\
$516 \mathrm{~A}$ & $30^{\circ} 16^{\prime} 59$ & $35^{\circ} 17^{\prime} 12$ & 1313.0 & 12 & 8 \\
517 & $30^{\circ} 56^{\prime} 81$ & $38^{\circ} 02^{\prime} 47$ & 2963.0 & 24 & 100 \\
518 & $29^{\circ} 58^{\prime} 42$ & $38^{\circ} 08^{\prime} 12$ & 3944.0 & 19 & 20 \\
\hline
\end{tabular}

bigerinita glutinata, Globigerinoides conglobatus, $G$. ruber (white), G. ruber (pink), G. trilobus, G. sacculifer, Globorotalia crassaformis group, G. crassula, G. hirsuta, G. inflata, G. menardii group, G. scitula, G. tosaensis, G. triangula, G. truncatulinoides left-coiling, $G$. truncatulinoides right-coiling, Globorotaloides hexagona, Hastigerina siphonifera, Orbulina universa, Pulleniatina obliquiloculata, Sphaeroidinella dehiscens. Some of them are differentiated in morphotypes, whereas others are grouped together.

\section{Quaternary Zonation}

Establishment of the biostratigraphic scale based on planktonic foraminifers depends upon several criteria (Hedberg, 1972), mainly the extinctions and/or appearances of taxa. In the Quaternary, the faunal stock of the lower Pleistocene persists even today (Berggren, 1969).
The faunal frequency changes, and disappearances and appearances reflect environment modifications (Pujol, 1981). The extinction and nonevolutionary appearances of planktonic foraminifers are time transgressive from one ocean basin to another (Kennett, 1970).

Investigations of the Quaternary marine section in recent years has led to the creation of subdivisions (Blow, 1969; Lamb and Beard, 1972; Bolli and Premoli Silva, 1973). Several zonal patterns have in fact, been suggested for subdivisions of sediments of this age. The quality of the sample and the elements used determine the differences in these biozonations. In fact, biostratigraphic subdivisions of Quaternary sediments formed during a short geologic period (1.8 m.y.) could be considered only as Globorotalia truncatulinoides s.1. Zone. This zone is then subdivided into 2 subzones: $G$. truncatulinoides Partial Range Zone (N22) and Globigerina calida calida-Sphaeroidinella excavata Assemblage Zone (N23). This zonation scheme has been applied to much of the deep-sea drilling data. But when the sampling sequence is studied in detail, it is very difficult within temperate sites to discern the boundary between $\mathrm{N} 23$ and N22 zones.

With abundant Quaternary sediment, Bolli and Premoli Silva (1973) established the Globorotalia truncatulinoides Zone and its five subzones: $G$. crassaformis viola, G. crassaformis hessi, Globigerina calida calida, G. bermudezi, and Globorotalia fimbriata. These subzones 
have since been applied to sedimentary sections from the Mid-Atlantic Ridge (DSDP Legs 45 and 46; Krasheninnikov, 1978); near the western African coast (Leg 41; Pflaumann and Krasheninnikov, 1978) and in the Indian Ocean (Leg 27; Rögl, 1974). Such a wide geographic extension underlines the subzones' chronostratigraphic nature. A precise correlation with a Quaternary time scale is, however, hazardous, especially with the species G. fimbriata or Globigerina bermudezi. The juxtaposition of different biogenic variations $(\mathrm{FAD}=$ first appearance datum, or LAD = last appearance datum) with isotopic curves seems to have good stratigraphic value, especially in the upper part of the Quaternary (Berggren et al., 1980; Pujol, 1980).

\section{Biozonation}

The distribution of some taxa helped us to divide the Globorotalia truncatulinoides zone into five different subzones (Fig. 2). Variations in the frequency and in the coiling trends for this species provide some environmental indications but emphasize the subdivisions. This differentiation is based principally on $10-\mathrm{cm}$ sampling intervals at Site 517. A comparison is then made with the other Leg 72 sites.

\section{Subzone A}

Definition. Range of Globorotalia hirsuta.

Remarks. G. hirsuta is a descendant of G. praehirsuta (Blow, 1969): “ $G$. (G.) hirsuta praehirsuta gives rise to $G$. (G.) hirsuta hirsuta within the earlier parts of Zone N21"'. Yet, in the Quaternary sequences of the northeastern Atlantic, this species is only observed in the upper part of the Quaternary. It first appeared near the LAD of Pseudoemiliania lacunosa (Pujol, 1980), dated around $0.45 \mathrm{Ma}$ (Thierstein et al., 1977).

The first $G$. hirsuta occurrence at Site 517 is in Sample $517-2-1,120-122 \mathrm{~cm}$. This level corresponds to Isotopic Stage 11 (Vergnaud Grazzini et al., this volume). Acceptance of the isotopic stratigraphy leads to an age estimate of about $400,000 \mathrm{yr}$. If only core catchers are analyzed, the LAD of Pseudoemiliania lacunosa is recognized in Core 517-2,CC (see site chapter, Site 517, this volume). Even through the FAD of $G$. hirsuta is located in Stage 11, its relative abundance increases in Sample $516-1-2,80-82 \mathrm{~cm}$. This level is situated in Isotopic Stage 7 (Vergnaud Grazzini et al., this volume), as is the FAD of this species in the Vema Channel (Williams and Ledbetter, 1979). The reason for stratigraphic difference is not clear, but it could be a result of the particular paleooceanography of the Vema Channel (Johnson et al., 1977; Ledbetter and Johnson, 1976).

The coiling trend of $G$. hirsuta also gives some biostratigraphic information (Pujol, 1975; Pujol and Duprat, 1977; Pujol, 1980). Today, this species shows a preference for a right coiling; in the last glacial stages (Isotopic Stages 2 and 4 ) it was dominantly left coiling, and between the LAD of Pseudoemiliania lacunosa and Isotopic Stage 5, it again shows a right-coiling dominance.

Only a right-coiling population occurs at Site 517 . The absence of the left-coiling specimens in the upper cores could be due either to the nonrecovery of uppermost sediment or to the nonrecognition of the isotopic stages because of broad sampling. The first assumption seems to be the most probable one. The absence of $G$. fimbriata and Globigerina bermudezi (index taxon of the more recent subzones of Bolli and Premoli Silva, 1973) could suggest missing surficial sediment, but we think that this absence is only ecological. The biogeographic area of this species is located near the equator.

\section{Subzone B}

Definition. Interval between the decrease of the frequency of Globorotalia crassaformis and the first occurrence of $G$. hirsuta.

Remarks. In the Vema Channel, G. crassaformis disappears in Isotopic Stage $5(120,000$ yr. ago) (Williams and Ledbetter, 1979). This species occurs in the upper part of the Leg 72 holes. In Cores 517-1 and 517-2, the distribution of $G$. crassaformis is sporadic and its frequency very low, so it is difficult, if not impossible, to compare this distribution to the time scale given by Williams and Ledbetter (1979). Again, an increase of velocity of the AABW flowing through the Vema Channel could cause the disappearance of G. crassaformis in Isotopic Stage 5 (Ledbetter, 1979).

\section{Subzone C}

Definition. Interval between the LAD of Globigerina eggeri and the decrease of Globorotalia crassaformis group.

Remarks. As in the preceding subzone definition, the datum of this subzone base probably marks an ecozone.

\section{Subzone D}

Definition. Interval between the LAD of Globorotalia crassula $(=G$. crassaformis viola $)$ and the last occurrence of Globigerina eggeri.

Remarks. Both Globorotalia inflata and G. crassaformis increase in relative abundance. This subzone is comparable to the G. crassaformis hessi Subzone (base) of Bolli and Premoli Silva (1973) and may reflect environmental conditions.

\section{Subzone $\mathbf{E}$}

Definition. Interval between the FAD of Globorotalia truncatulinoides and the LAD of $G$. crassula $(=G$. crassaformis viola).

Remarks. Globorotalia triangula is present, and $G$. tosaensis is rare. Our definition of $G$. crassula also includes $G$. crassaformis viola; this subzone is biostratigraphically equivalent to the $G$. crassaformis viola Subzone of Bolli and Premoli Silva (1973).

\section{Correlation of Leg 72 Sites}

Recognition of the different subzones defined for Site 517 is difficult for the other sites of Leg 72, because of: 1) the low abundance of planktonic microfauna and/ or their bad preservation (Holes 515, 515A, and 518); 2) low Quaternary sedimentation rate; 3 ) the restricted number of samples examined. Nonetheless, Figure 3 shows the distribution of subzones in the other holes. 


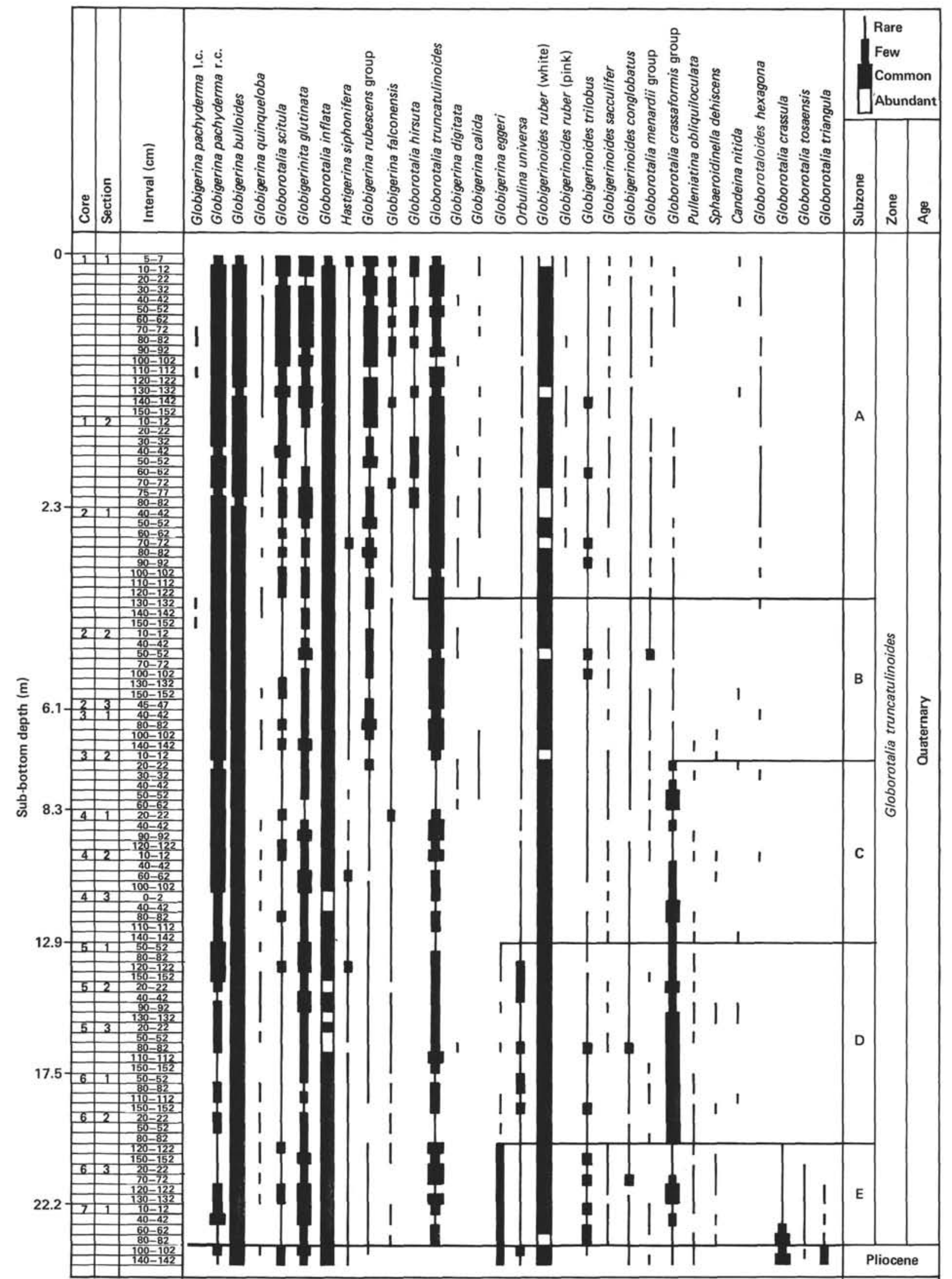

Figure 2. Quaternary biostratigraphy and planktonic foraminifers of Site 517 (Leg 72; southwestern Atlantic). Voids are excluded from the depth scale. 1.c. = left coiling; r.c. = right coiling. 


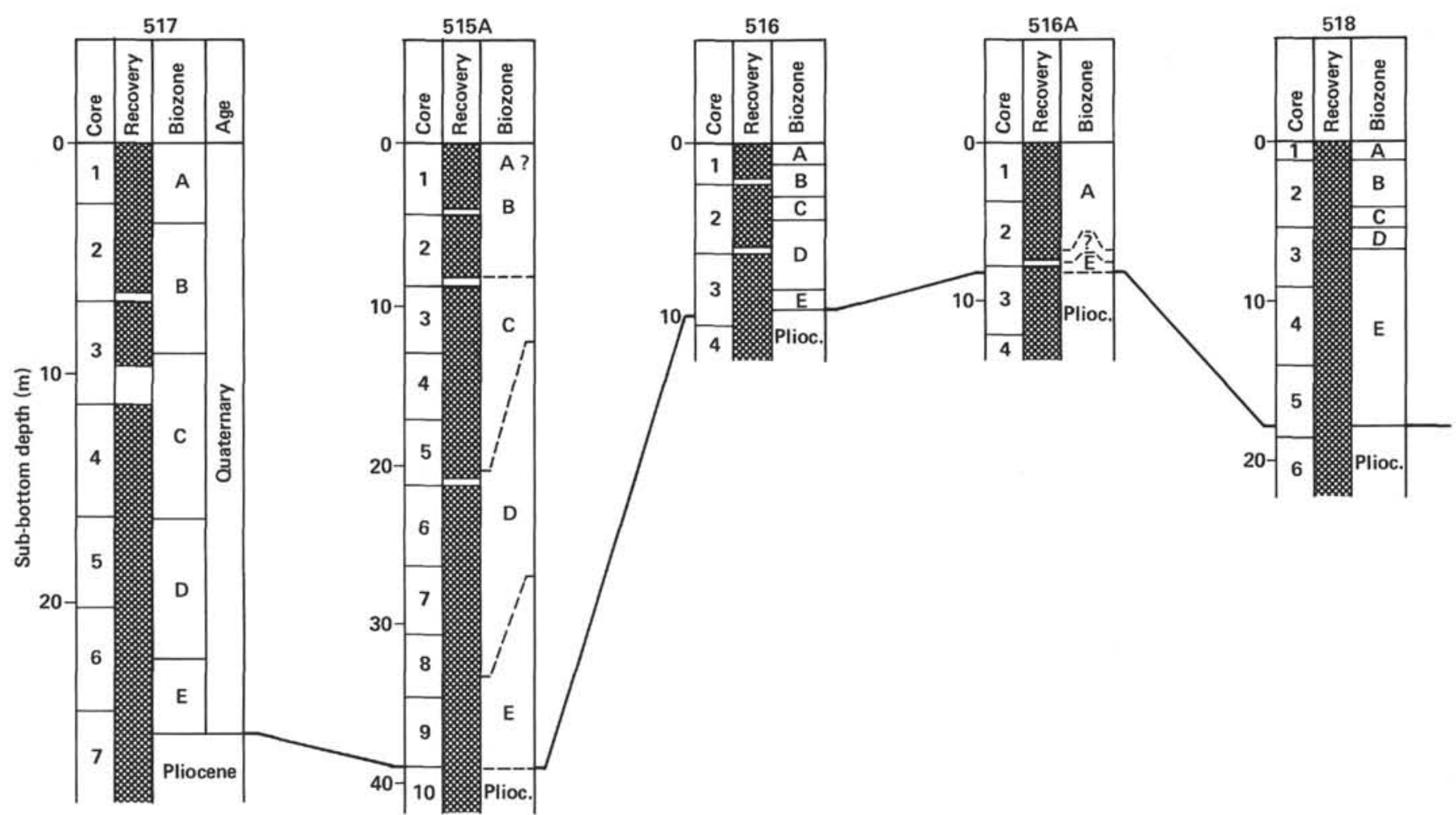

Figure 3. Biostratigraphic correlation of the Quaternary sequence in the southwestern Atlantic (Rio Grande Rise, Leg 72). (Plioc. = Pliocene.)

On the Rio Grande Rise (Holes 516 and 516A), Globorotalia truncatulinoides appears at Samples 516-3-2, $30-32 \mathrm{~cm}$ and 516A-2, CC (some contamination in Sample $516 \mathrm{~A}-3, \mathrm{CC}$ ). Subzone A is recognized in the two holes. The planktonic microfauna are abundant, and the surface sediment contains many pteropods. Subzones B, C, and D do not occur in Hole 516A, but these three subzones can be recognized in Hole 516. G. truncatulinoides is left coiling in Subzones B and C but shows random coiling in Subzone D. G. crassula is observed in Section 516-3-2; G. truncatulinoides is again left coiling. The Quaternary sequence is about $9 \mathrm{~m}$ thick at Site 516, but is thicker on the west flank of the Rio Grande Rise (Site 517). G. truncatulinoides appears at about $25.3 \mathrm{~m}$ sub-bottom depth or $23 \mathrm{~m}$ depth if we take into account the percentage of sample recovered (Sample $517-7-1,80-82 \mathrm{~cm}$ ). The different subzones defined for Site 517 are adjusted to exclude the void spaces (Fig. 3).

In the southern Brazil Basin (Site 518), a good Quaternary sequence was retrieved from Core 518-1 to Sample $518-5-3,70-72 \mathrm{~cm}$. Some probable contamination exists in samples from Section 518-6-1, but the different subzones are identified. Planktonic foraminifers are abundant to common, and the preservation is generally good to moderate. Dissolution is low to high. It is especially high in Subzones D and E and at the base of Subzone A.

Within the Brazil Basin, Quaternary sediments were recovered in Holes 515 and 515A by the hydraulic piston corer (HPC). Assemblages in these cores are strongly dissolved. On the basis of the FAD $G$. truncatulinoides, Cores 515-1 and 515-2 are assessed to be Quaternary.
Core 515-2 could belong to Subzone E ( $G$. triangula). In Hole $515 \mathrm{~A}$, Cores 1 to 10 are Quaternary ( $42 \mathrm{~m}$ of sediment). Biostratigraphic differentiation is not possible.

\section{Stratigraphic Interpretation}

All subzones defined and based on planktonic foraminifers are correlated with Zones N22/N23 of Blow (1969). The appearance of Globorotalia truncatulinoides defines the base of the Quaternary. Because of the definition of the N22/N23 boundary, it is impossible to translate it in subzone terms. In fact, the definition of Zone N23 seems to contain some regional restrictions. When comparing established subzones with those of Bolli and Premoli Silva (1973), we can make some hypothetical correlations on the basis of species distribution. Our lower Quaternary Subzone E could be equivalent to the $G$. crassaformis viola Subzone. The frequency of the G. crassaformis group and the appearance of Globigerina calida at the base of Subzone E allow correlation of Subzones C and D to the Globorotalia hessi Subzone. Finally, Subzones A and B could be equivalent to the Globigerina calida calida Subzone. This implies the absence of the $G$. bermudezi and Globorotalia fimbriata Subzones, at least in Site 517.

Core 517-1 probably penetrated the sea floor interface at least 4 times before its retrieval, based on a repeated lithologic succession of gray pteropod-foraminiferal ooze. Sampling was avoided whenever there was repetition of coarse sand pteropod-rich laminae. This coring problem is perhaps a reason for the absence of the upper part of the Quaternary at Site 517 and for the difficulty in recognizing the last glacial stages, especially those 
marked by left-coiling $G$. hirsuta. Abundance of pink Globigerinoides ruber and pteropods, however, indicate that the surface sediment is Recent.

The combination of the sequence of species occurrence and oxygen isotope stratigraphy allows some age estimations. The first occurrence of Globorotalia hirsu$t a$ in Sample $517-2-1,120-122 \mathrm{~cm}$ is near the LAD of Pseudoemiliania lacunosa (see site chapter, Site 517, this volume), indicating an age of about $400,000 \mathrm{yr}$. The increase of $G$. hirsuta slightly higher (Sample 517-1-2, $81-82 \mathrm{~cm}$ ) probably correlates with its FAD in the Vema Channel beginning with Isotopic Stage 7 (Williams and Ledbetter, 1979). The presence of Globorotaloides hexagona in the surface sample and an apparent absence of left-coiling Globorotalia hirsuta indicate the absence of the last glacial sediment or mechanical coring perturbation of that deposit.

Oxygen isotope stratigraphy provides an additional stratigraphic framework. Emiliani $(1955,1966)$ numbered Quaternary planktonic foraminiferal Isotopic Stages 1 to 15 , and Shackleton and Opdyke $(1973,1976)$ increased that number to 23 stages. Oxygen and carbon isotope analyses of benthic as well as planktonic foraminifers (Vergnaud Grazzini et al., this volume) also provided a good stratigraphic frame for Site 517. Thirtyseven isotopic stages corresponding to 19 glacial cycles have been identified. Our faunal zonation is directly related neither to these cycles nor to surface temperatures. Some major faunal changes, such as that of $G$. crassaformis, however, might correspond to important glacial advances (Isotopic Stage 22). Subzone E (Samples $517-7-1,100 \mathrm{~cm}$ to $517-6-2,110 \mathrm{~cm}$ ) is also related to a time of minor glacial effect. Subzone D (Samples 517-6$2,110 \mathrm{~cm}$ to $517-4-3,150 \mathrm{~cm}$ ) corresponds to Stages 34 to 25 . An increase from 4 to about $5 \%$ in the $\delta^{18} \mathrm{O}$ values occurs progressively throughout this subzone, reaching a maximum in Stage 22 at the base of the Subzone C (Samples 517-4-3, $140 \mathrm{~cm}$ to 517-3-2, $20 \mathrm{~cm}$ ). Subzone B (Samples 517-3-2, $10 \mathrm{~cm}$ to $517-2-1,120 \mathrm{~cm}$ ) and A (Samples 517-2-1, $110 \mathrm{~cm}$ to $517-1-, 0-2.5 \mathrm{~cm}$ ) are related to the last glacial cycle, to Stages 15 to 12, and Stages 11 to 1 , respectively.

The paleomagnetic study of Hamilton and others (this volume) further refines a precise time scale of our biozonation and its correlation with the isotopic stratigraphy. The reversed interval immediately below $25 \mathrm{~m}$ sub-bottom correlates with the lower part of the Matuyama Epoch, defining Subzone E as the base of the Pleistocene. At about $15 \mathrm{~m}$ sub-bottom (Core 517-4), another change of polarity could represent the base of the Jaramillo, dated at about $0.94 \mathrm{Ma}$ (Berggren et al., 1980). If we accept the isotopic stratigraphy (Vergnaud Grazzini et al., this volume), the Jaramillo Event should bracket Isotopic Stage 24; this estimate permits a more precise assignment of this age to the interval between Samples $517-4-3,100 \mathrm{~cm}$ and $517-4-3,180 \mathrm{~cm}$.

The Brunhes-Matuyama $(0.73 \mathrm{Ma})$ reversal is placed between Cores 517-3 and 517-4 (Hamilton et al., this volume). But the location of the Brunhes/Matuyama boundary at the transition from Stage 19 to Stage 20 permits us to assign this age to Sample $517-4-2,10 \mathrm{~cm}$
(Vergnaud Grazzini et al., this volume), and to calculate an average sedimentation rate of $1-3 \mathrm{~cm} / 10^{3} \mathrm{yr}$. for the upper part of the sequence. These results are summarized in Figure 4 and are in good agreement with the placement of events proposed by Hamilton and others (this volume.

\section{ENVIRONMENTAL INVESTIGATIONS}

\section{Oceanographic Setting}

The circulation in the South Atlantic Ocean includes large subtropical anticyclonic gyre roughly similar to that seen in other oceans. This gyre is bounded on the east by the Benguela Current, on the north by the South Equatorial Current, on the west by the Brazil Current, and on the south by Westwind Drift.

The different sites of Leg 72, particularly Site 517 from which a detailed study of planktonic foraminifers is made, are located in the Brazil Current (Fig. 5). The Brazil Current transports South Equatorial Water southward along the east coast of South America. It meets the cold, northward-flowing Falkland Current at approximately $35^{\circ} \mathrm{S}$, and the two swing eastward to form the South Atlantic Current. Thus, at about 35 to $38^{\circ} \mathrm{S}$, the Brazil Current reaches the subtropical convergence.

The temperature of the surface water of the Brazil Current near the Rio Grande Rise varies throughout the year between 20 and $25^{\circ} \mathrm{C}$, but at a depth of about 100 $\mathrm{m}$, it remains at a constant $20^{\circ} \mathrm{C}$. Surface salinity is $36.5 \%$ in January and $36 \%$ in August and is stable at about $36 \%$ at $100 \mathrm{~m}$ depth.

Principally, a subtropical microfauna with a low percentage of subantarctic elements inhabit the surface waters of the Leg 72 study area today. Species typical of subtropical waters are: Globigerinoides trilobus, G. ruber, Globorotalia menardii, and Hastigerina siphonifera (Boltovskoy, 1970; Lena and Watanabei, 1981). In waters near the Brazil coast or in those forming the prolongation of the Falkland Current Globigerinoides ruber increases and $H$. siphonifera decreases in relative abundance (Boltovskoy, 1970).

Different studies of the plankton collected in the South Atlantic (Bé and Tolderlund, 1971; Bé, 1977; Boltovskoy, 1968, 1970, 1976) spot the absence and occurrence of the more important species. Among the key species not present in the biocenose of this area are the Antarctic species Globigerina pachyderma (left-coiling varieties) and the sub-Antarctic species $G$. pachyderma (right-coiling), G. bulloides, and G. quinqueloba.

Northern subtropical species present in the region include: Globorotalia inflata $(<5 \%)$, Globigerinita glutinata $(<5 \%)$, Orbulina universa $(<5 \%)$, Hastigerina siphonifera $(<5 \%)$, Globorotalia hirsuta $(<5 \%)$, and $G$. truncatulinoides $(<5 \%$, ratio of coiling: random to leftcoiling dominant).

Southern subtropical and tropical species include: Globigerinoides ruber ( $>50 \%$ ), Globorotalia crassaformis $(<5 \%)$, Globigerinoides conglobatus $(<5 \%)$, Globorotalia menardii $<5 \%$ ), Pulleniatina obliquiloculata $(<5 \%)$, and Globigerinoides trilobus $(20-50 \%)$. 

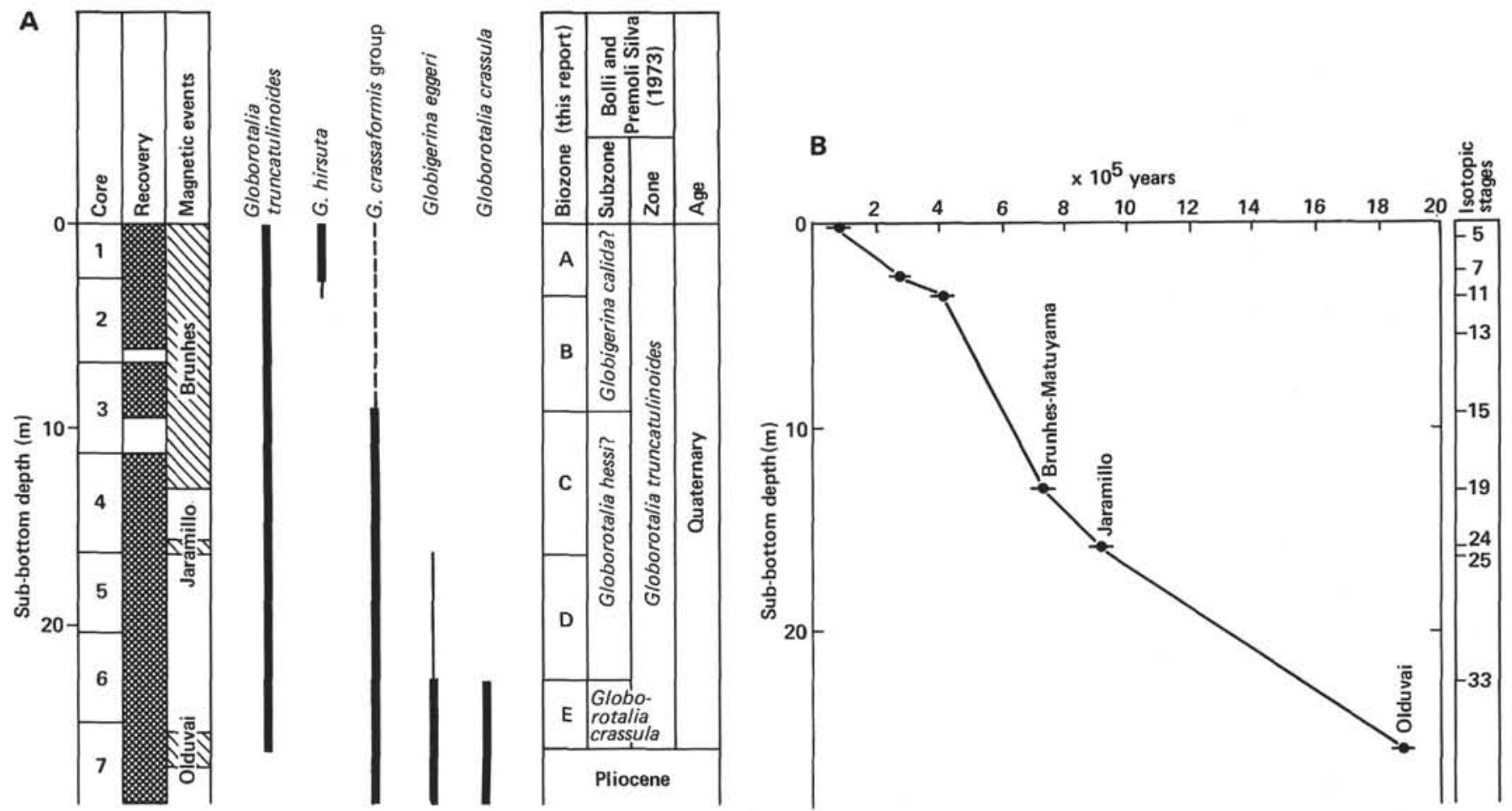

Figure 4. A. Biostratigraphic summary of Site 517 (Leg 72). Hypothetical time scale of the Quaternary sequence and rate of sedimentation presumed. B. Quaternary biozonation scheme and datum levels; isotopic stages from Vergnaud Grazzini and others (this volume); magnetic reversal epoch boundaries from Hamilton and others (this volume).

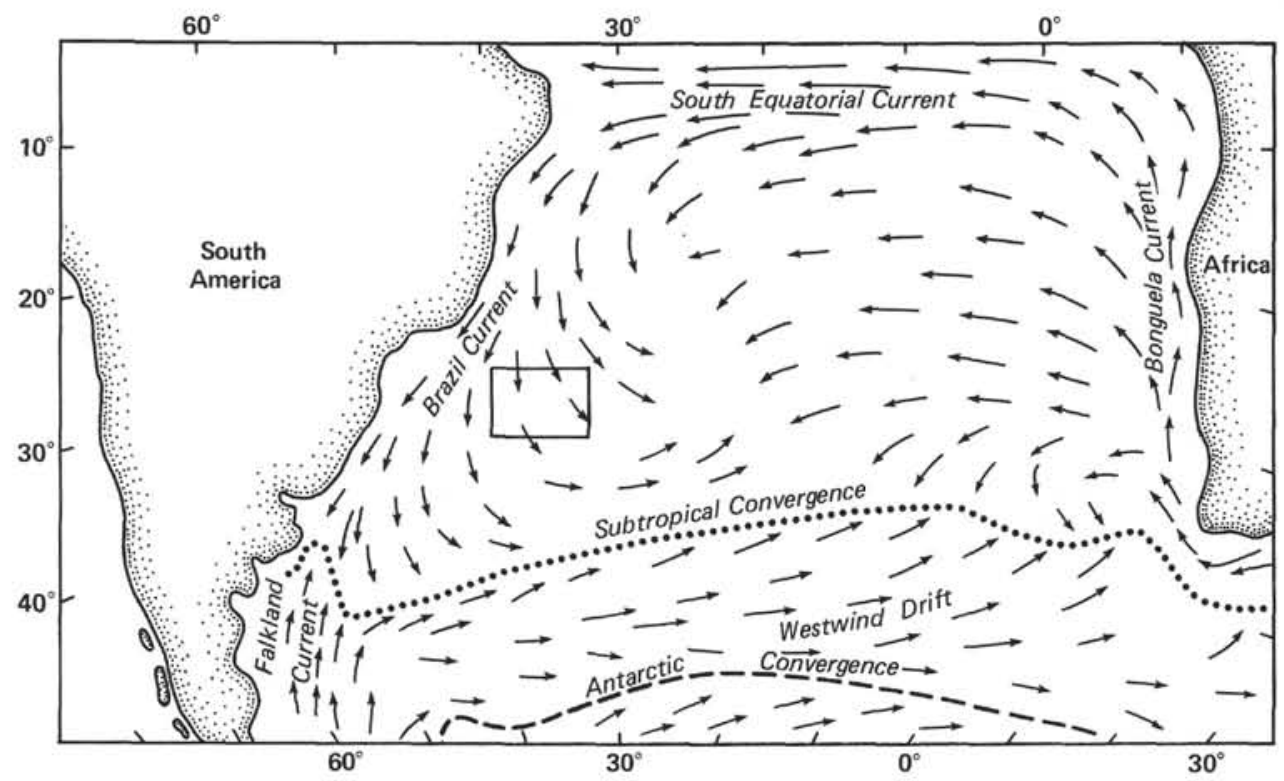

Figure 5. Hydrologic setting for the Leg 72 study area.

The spatial distribution of the more important species and their frequency are given in Figure 6. The distribution of these species reflects the structure of the surface waters of the region. Sub-Antarctic species (Globigerina pachyderma, G. bulloides) are bounded by the antarctic convergence, and subtropical species (e.g., Globigerinoides ruber) are bounded by the subtropical convergence. The transitional species Globorotalia inflata has an intermediate position, and the distribution of left-coil- ing and right-coiling populations of $G$. truncatulinoides show a gradual succession between a southern left-dominated population and northern right-dominated population (Fig. 6E).

\section{METHODS}

We used the present-day ecological responses of these species of planktonic foraminifers to investigate the hydrologic variations during the Quaternary. This approach is based on the eventual displacement of the different water masses and particularly the subtropical 
A

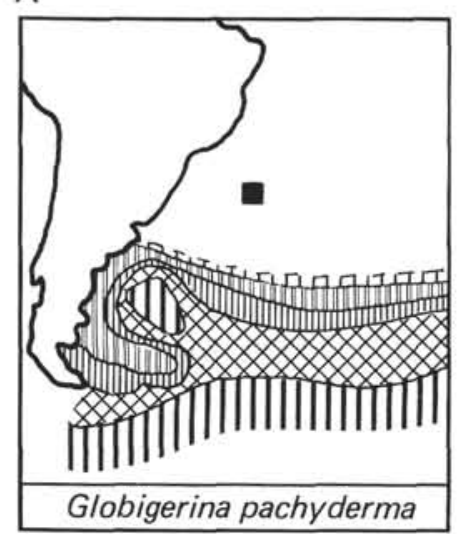

D

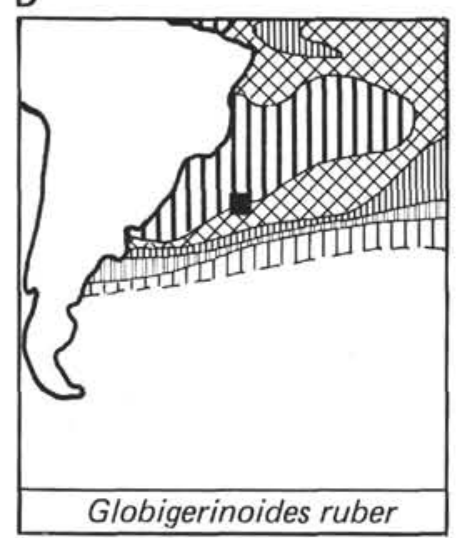

B

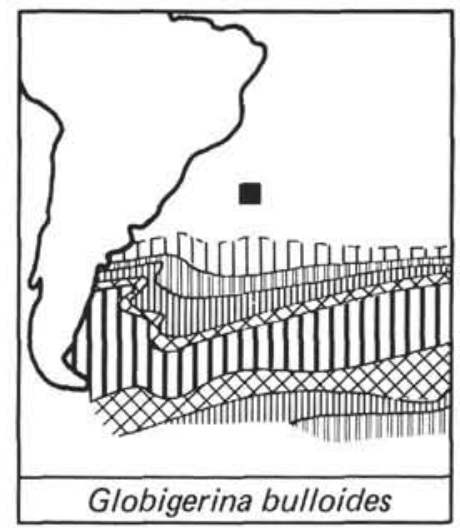

E

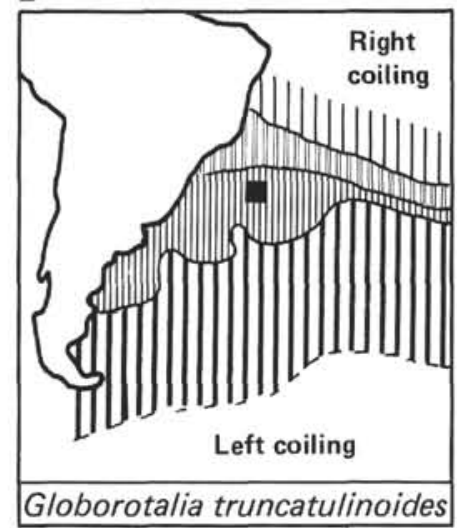

C

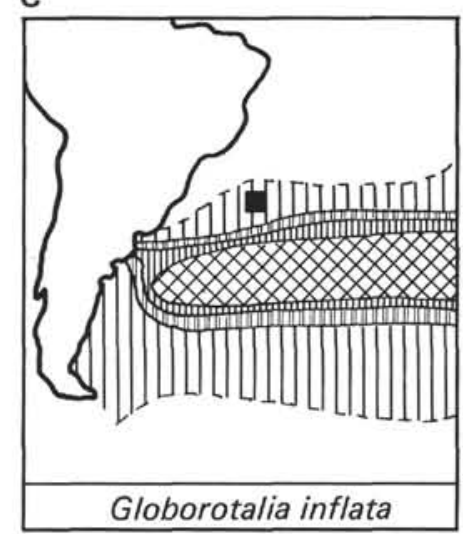

Legend ( $A-D)$

III $>50 \%$

X 20-50

이미 10-19

而 5-9

미 $<5$

Legend (E)

III $>99 \%$

血而 50-99

[IIIII] $2-49$

एII $<2$

Figure 6. Distribution and frequency of some planktonic foraminifers in the surface waters near Site 517 (southwestern Atlantic, Leg 72); from Bé (1977); Bé and Tolderlund (1971). Percentage ratios of left-coiling versus rightcoiling species.

convergence, variations that could be reflected by frequency variations of the planktonic foraminifers.

Irregularities of the faunal composition in surface waters and on the sea floor can be related to changes in temperature. Despite demonstrations that the distribution of planktonic species is not solely determined by temperature (Cifelli, 1971), this type of investigation can depict the paleohydrology. In this way, pertinent data for climatologic analyses were obtained from publications dealing with the ecology of planktonic foraminifers. A good approach to studying climatic variations would be the identification and classification of species according to temperature range (for instance, cold-water indicators or warmwater indicators). The matrix of percentage of the different species for each sample from Site 517 are factor analyzed, in order to arrange the species in groups objectively.

\section{Environmental Interpretation of Site $\mathbf{5 1 7}$}

This interpretation is made from the base to the top of the Quaternary sequence (Samples 517-7-1, 80-82 cm to $517-1-1,0-2.5 \mathrm{~cm}$ ) and in the succession of each subzones. The investigations are based on three sorts of data. First, their climatic values are considered and the species frequencies are arranged from left to right, cold species on the left side and warm on the right (Fig. 2). The figure, used previously for biostratigraphy, shows the increase or decrease through the sequence of temperature-ordered species.

A detailed analysis of variations of these 30 species is complicated; therefore, for the second type of data, we factor-analyzed this data in order to deduce the number of dimensions of the matrix. The results of this Q-mode analysis form our second data base. The analysis of the percentages of the 30 different species observed in 100 samples from Site 517 are condensed to 10 categories for a cumulative variance of $99.63 \%$. We interpret these categories as representing assemblages of planktonic foraminifers. We retained three factor-assemblages with a variance of $31.7 \%, 38.4 \%$, and $26.1 \%$, respectively (Fig. 7, Tables 2 and 3).

In Factor 1, right-coiling Globigerina pachyderma and, to a lesser extent, left-coiling Globorotalia truncatulinoides are the dominant forms. The distribution of these species suggests a displacement of the subtropical convergence from south to north.

Factor 2 is an intermediate assemblage in which $G$. inflata and, to a lesser degree, Globigerina bulloides are the most important species. It can probably account for the displacement from the south $\left(40-45^{\circ} \mathrm{S}\right)$ to the north $\left(30^{\circ} \mathrm{S}\right)$ of the South Atlantic Current.

A single species, Globigerinoides ruber, dominates Factor 3 and represents the subtropical influence of the Brazil Current.

The coiling ratio of Globorotalia truncatulinoides is a key paleoenvironmental indicator. In present subtropical surface water of the site location, the population of G. truncatulinoides is composed of about $50 \%$ leftcoiling form. Following this distribution (Fig. 8), we think that Quaternary fluctuations of the hydrologic regime will also produce changes in the populations of $G$. 


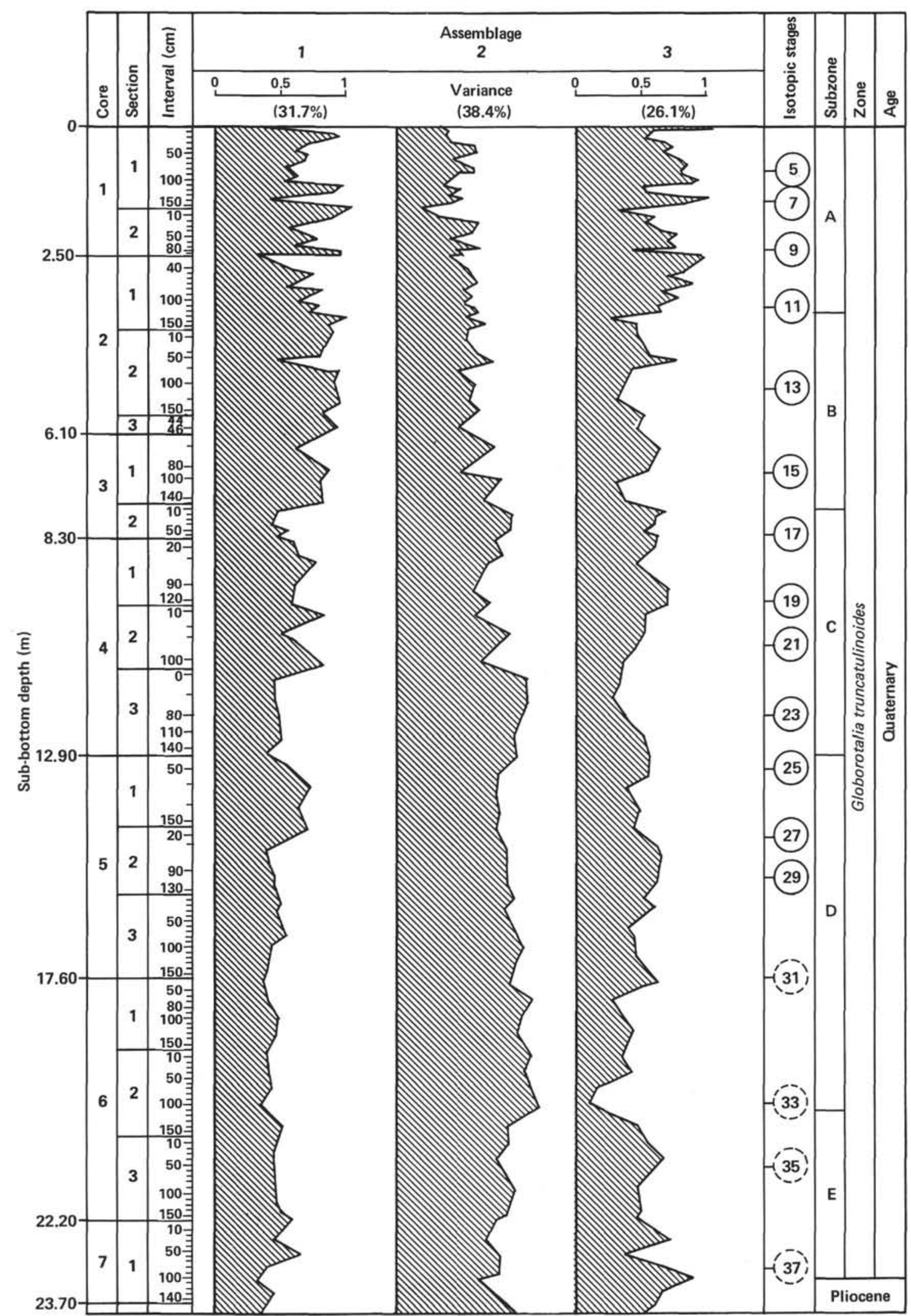

Figure 7. Varimax assemblage derived from factor analysis of planktonic foraminiferal frequency in Site 517. Voids are excluded from the depth scale. Isotopic stages from Vergnaud Grazzini and others (this volume). 
Table 2. Varimax factor matrix from factor analysis of Hole 517.

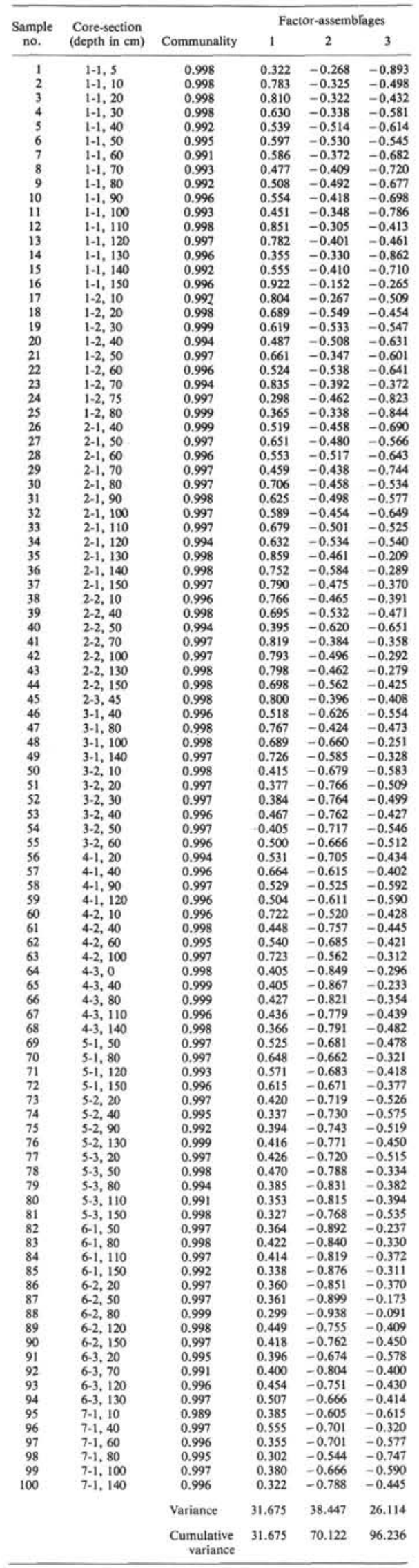

Table 3. Varimax factor score matrix (species matrix) from factor analysis of Hole 517.

\begin{tabular}{|c|c|c|c|}
\hline \multirow[b]{2}{*}{ Species } & \multicolumn{3}{|c|}{ Factor-assemblage } \\
\hline & 1 & 2 & 3 \\
\hline Globigerina pachyderma (left-coiling) & 0.005 & 0.002 & 0.001 \\
\hline G. pachyderma (right-coiling) & 0.809 & 0.217 & 0.093 \\
\hline G. bulloides & 0.197 & -0.354 & 0.021 \\
\hline G. quinqueloba & 0.006 & 0.005 & -0.014 \\
\hline Globorotalia scitula & 0.065 & 0.087 & -0.216 \\
\hline Globigerinita glutinata & 0.044 & -0.040 & -0.159 \\
\hline Globorotalia inflata & 0.194 & -0.819 & 0.165 \\
\hline Hastigerina siphonifera & 0.007 & -0.020 & -0.034 \\
\hline Globigerina rubescens & 0.097 & 0.144 & -0.270 \\
\hline G. falconensis & 0.055 & 0.034 & -0.065 \\
\hline Globorotalia hirsuta & -0.013 & 0.048 & -0.132 \\
\hline G. truncatulinoides (right coiling) & -0.000 & -0.004 & -0.068 \\
\hline G. truncatulinoides (left coiling) & 0.480 & 0.092 & 0.111 \\
\hline Globigerinoides ruber (white) & 0.124 & -0.223 & -0.872 \\
\hline Globigerina digitata & -0.000 & 0.001 & -0.005 \\
\hline Orbulina universa & -0.017 & -0.049 & -0.032 \\
\hline Globigerinoides ruber (pink) & -0.001 & 0.007 & -0.017 \\
\hline G. conglobatus & -0.000 & -0.021 & -0.025 \\
\hline G. trilobus & 0.008 & -0.018 & -0.063 \\
\hline G. sacculifer & 0.000 & 0.002 & -0.021 \\
\hline Globigerina eggeri & -0.016 & -0.018 & -0.006 \\
\hline Globigerinoides tenellus & -0.000 & -0.000 & -0.000 \\
\hline Globigerina calida & -0.002 & 0.004 & -0.016 \\
\hline Globorotalia crassaformis group & -0.065 & -0.248 & 0.106 \\
\hline G. menardii group & 0.006 & 0.005 & -0.020 \\
\hline Pulleniatina obliquiloculata & -0.004 & -0.014 & 0.005 \\
\hline G. tumida & -0.000 & -0.000 & -0.000 \\
\hline Sphaeroidinella dehiscens & -0.002 & -0.005 & 0.001 \\
\hline Turborotalita humilis & -0.000 & -0.000 & -0.000 \\
\hline Candeina nitida & -0.001 & -0.000 & -0.003 \\
\hline G. tosaensis & -0.003 & -0.004 & -0.001 \\
\hline G. triangula & -0.001 & -0.001 & 0.000 \\
\hline Globorotaloides hexagona & 0.005 & 0.012 & -0.019 \\
\hline
\end{tabular}

truncatulinoides. The variation of the frequency of leftcoiling and right-coiling individuals of this species in the Quaternary sequence is interpreted in this way: increase of the left-coiling form corresponds to an amplification of the southern hydrologic influence (cold); increase of the right-coiling individuals suggests an intensification of the warm Brazil Current.

Two broad intervals can be differentiated within the Quaternary sequence. From the base to Subzone C, the first one is characterized by the importance of Factor 2 (G. inflata principally) and by a certain monotony of the frequency of the other species. The dominance of Factor 2 in Subzones C (lower half), D, and E reflects the lack of important hydrologic change in the investigated area during the periods of the subzones.

The second episode corresponds to the upper Subzones $\mathrm{A}, \mathrm{B}$, and $\mathrm{C}$ and is differentiated by the increase of Factor 1 and by rapid fluctuations between cold species such as Globigerina pachyderma (Factor 1) and warm species such as Globigerinoides ruber (Factor 2). These three upper subzones seem to represent a conflicting period between the warm Brazil Current influence and the rise of a southern hydrologic influence. The boundary between these two broad periods is situated in the middle of Subzone C. It could be underlined by rapid and strong pulsations of left-coiling Globorotalia truncatulinoides. Indeed, from the base of the Quaternary to the middle of Subzone C (approximately Section 


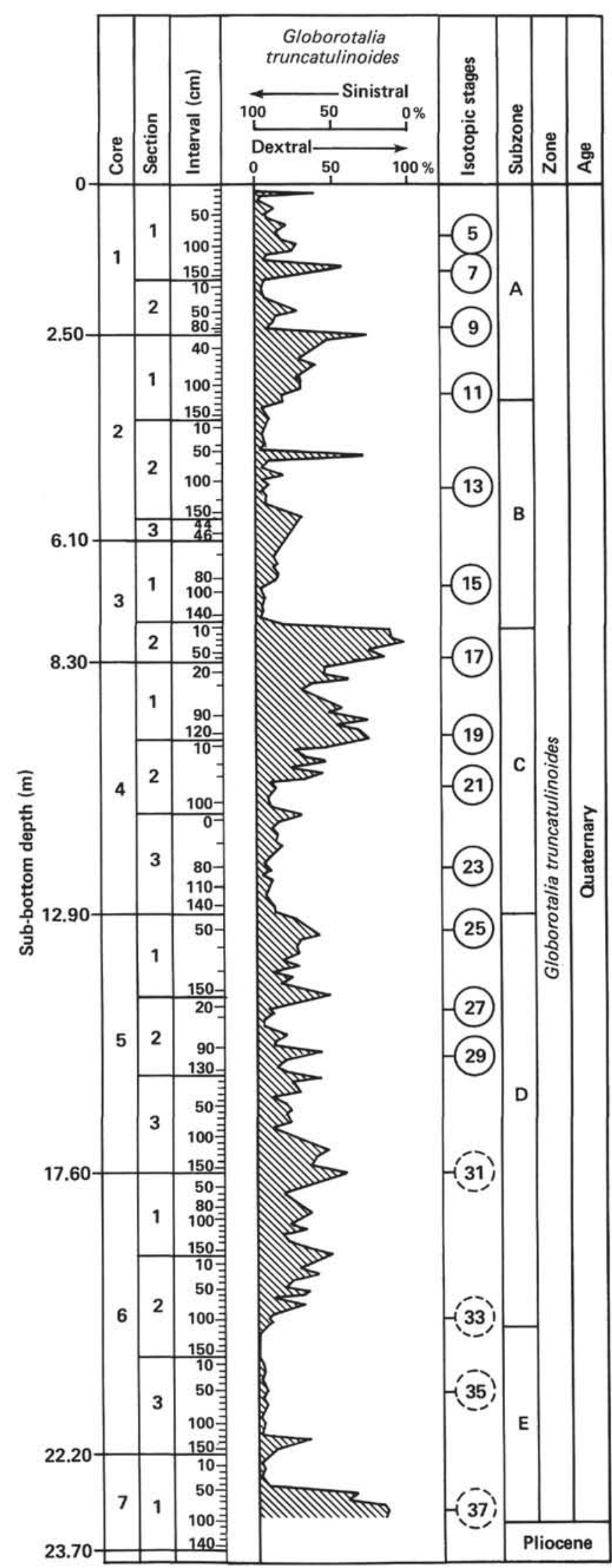

Figure 8. Coiling ratio of Globorotalia truncatulinoides in the Quaternary of Site 517 (southwestern Atlantic, Leg 72). Voids are excluded from the depth scale. Isotopic stages from Vergnaud Grazzini and others (this volume).
517-4-2) the G. truncatulinoides population is dominantly left coiling, with few right-coiling pulsations. These pulsations appear in the upper part of Subzone $C$ and again in Subzones A and B.

\section{CONCLUSIONS}

The Quaternary sequence of the Rio Grande Rise area records two hydrologic periods. The more recent one begins at Isotopic Stage 19 (Brunhes Event) and corresponds to an interval with rapid fluctuations between the warm Brazil Current and the cold Falkland Current or extension of the subtropical convergence, in turn indicating more rapid or more differentiated climatic cycles. The older period is clearly different and shows only a few variations, and these have low amplitude. This pattern corresponds to the results of the $\delta^{18} \mathrm{O}$ record (Van Donk, 1976), indicating that many of the glacial stages (especially before $1 \mathrm{Ma}$ ) are less pronounced than the more recent glacial maximum. The occurrence of this differentiation near the Jaramillo magnetic reversal event goes with the polarity assignment at Site 517 (Hamilton et al., this volume). That contrast was seen by Huang and Watkins (1977) between the Brunhes and Matuyama as caused by bottom-water activity in the South Pacific.

Three important pulsations of right-coiling Globorotalia truncatulinoides occur in the upper part of the Quaternary, indicating a cyclic variation of the surface hydrologic details. Considering the low sedimentation rate, details with regard to the chronology and the magnitude of the fluctuations are very difficult to obtain. Bioturbation, moreover, does introduce some distortion, but that is integrated into the general trends of the paleoclimatic response of sea surface temperature and atmospheric circulation, intensified during glacial periods. During glacial stages, the general atmospheric circulation of the winter seasons was intensified because of the increasing thermal gradient between the equator and poles, and, consequently, the oceanic circulation was strengthened (Climap Project Members, 1976). In Site 517 , this fact is represented, but it is difficult to give a precise interpretation of the different stages.

\section{PALEONTOLOGIC LIST}

In this section we discuss the different species observed; we include some indications about the nomenclature retained in the investigation, the abundance and the occurrence of each species in the Quaternary sequence, and their paleoclimatic values. The different specimens are deposited in the paleontologic collection of the Institut de Géologie du Bassin d'Aquitaine of the Université de Bordeaux (France).

Genus CANDEINA d'Orbigny, 1839

Candeina nitida d'Orbigny

(Plate 1, Figs. 1-2)

Candeina nitida d'Orbigny, 1839b, p. 108, pl. 2, Figs. 27-28; Bé, 1967, fig. 31 .

This tropical species is almost rare and has a sporadic distribution.

Genus GLOBIGERINA d'Orbigny, 1826

Globigerina bulloides d'Orbigny

(Plate 1, Figs. 3-5)

Globigerina bulloides d'Orbigny, 1826, p. 277, no. 1, modèles no. 17 (juvenile), no. 76 (adult); Banner and Blow, 1960, p. 3, pl. 1, figs. 1 (lectotype), 4; Be, 1967, Fig. 14. 
It would appear that occurrence and distribution of some subspecies or varieties depend upon ecological factors. Figures 3-5 of Plate 1 show the variability of the population accepted in this species.

Globigerina bulloides is considered as an epipelagic species and temperate-water and cool-water inhabitant. It is always common (10 to $20 \%$ ) in the Quaternary sequence.

\section{Globigerina calida Parker}

(Plate 1, Figs. 6-7)

Globigerina calida Parker, 1962, p. 221, pl. 1, figs. 9-11, Blow, 1969, p. 317 , pl. 13, figs. 9-10.

Range according to Bolli and Premoli Silva (1973) from the base of the Globigerina calida calida Subzone to present day. Here it appears at the base of Subzone B. Almost rare and sporadic in Subzones A and B.

\section{Globigerina digitata Brady}

(Plate 1, Figs. 8-9)

Globigerina digitata Brady, 1879, p. 286; Brady, 1884, p. 599 , pl. 80 , figs. 6-10; Bé, 1967, fig. 9.

This subtropical species is very rare.

\section{Globigerina eggeri Zobel \\ (Plate 2, Figs. 1-4)}

Globigerina dutertrei forma eggeri Zobel, 1968, pp. 109-110, fig. 2.

This form differs essentially from Globigerina dutertrei because of lack of teeth in the ombilic. In the variability of its population we accept the Globigerina "pachyderma-dutertrei intergrade" recognized by Kipp, 1976. This species disappears at the top of Subzone D.

\section{Globigerina falconensis Blow}

(Plate 2, Figs. 5-6)

Globigerina falconensis Blow, 1959, p. 177, pl. 9, figs. 40-41; Parker, 1962 , p. 224, pl. 1, figs. 14, 16-19; Malmgren and Kennett, 1977 , pl. 1, figs. 3-6.

This species could enter in the variability of the G. bulloides populations. But its geographic distribution in biocenosis (Cifelli and Smith, 1970) is slightly different from that of $G$. bulloides, implying another ecological control. In this Quaternary sequence, this species shows a frequency increase in Subzone A.

\section{Globigerina pachyderma (Ehrenberg)}

$$
\text { (Plate 2, Figs. 7-10) }
$$

Globigerina pachyderma Ehrenberg, 1861, p. 277, 278, 303; Ehrenberg, 1872, pl. 1, fig. 4.

Globigerina pachyderma (Ehrenberg). Brady, 1884, p. 600, pl. 114, figs. 19-20; Parker, 1962, p. 224, pl. 1, figs. 26-35, pl. 2, figs. 1-6; Bé, 1967, fig. 11.

No distinction is made between this and Globigerina incompta. Left-coiling specimens are very rare; right-coiling $G$. pachyderma increases from the upper part of Subzone D. This group is considered as the most important cool-water indicator.

\section{Globigerina quinqueloba Natland}

(Plate 3, Figs. 1-2)

Globigerina quinqueloba Natland, 1938, p. 149, pl. 6, fig. 7; Bé, 1967, fig. 10 .

We regard this species also as a distinct cool-water indicator. Its average size is around $150 \mu \mathrm{m}$ in diameter. So the frequency indication and perhaps its occurrence in all Quaternary sequences should be more important.

\section{Globigerina rubescens Hofker}

(Plate 3, Figs. 3-4)

Globigerina rubescens Hofker, 1956, p. 234, pl. 35, figs. 18-21.

This typical and small species is rare in the lower Quaternary and becomes common in Subzone A. Its average diameter is generally around $200 \mu \mathrm{m}$, so statistically it is often omitted.

\section{Genus GLOBIGERINITA Brönnimann, 1951}

Globigerinita glutinata (Egger)

(Plate 3, Figs. 5-6)

Globigerinita glutinata Egger, 1893, p. 371, figs. 19-21.

Globigerinita glutinata (Egger). Parker, 1962, p. 246, pl. 9, figs. 1-6; Bé, 1967, fig. 18.

The bulla is often not present. This species is scarce to common in the Pleistocene.

\section{Genus GLOBIGERINOIDES Cushman, 1927 Globigerinoides conglobatus (Brady) (Plate 3, Figs. 7-8)}

Globigerina conglobata Brady, 1879, p. 286; Brady, 1884, pl. 80, figs. 1-5; Banner and Blow, 1960, p. 6, pl. 4, fig. 4 (lectotype).

Globigerinoides conglobatus (Brady). Parker, 1962, p. 229, pl. 3, figs. 1-5; Bé, 1967, fig. 4a-b.

Globigerinoides conglobatus is a very thick-walled species that is treated as more resistant against dissolution than the other species of Globigerinoides. It is rare to scarce from the Pliocene to Present.

\section{Globigerinoides ruber (d'Orbigny) \\ (Plate 3, Figs. 9-10; Plate 4, Figs. 1-3)}

Globigerina rubra d'Orbigny, 1839, pl. 4, figs. 12-14.

Globigerinoides ruber (d'Orbigny) Bé, 1967, figs. 5a-c.

A differentiation is made between the pink and white forms. The white form is almost common to abundant. It seems to be one of the typical species of the southwestern Atlantic association. The pink form is rare and present only in Subzone A. A few pyramidilis forms (Plate 4, Fig. 3) are added in our statistics.

\section{Globigerinoides sacculifer (Brady)}

(Plate 4, Figs. 4-5)

Globigerina sacculifer Brady, 1877, p. 535; Brady, 1884, p. 604 , pl. 80 , figs. 11-17, pl. 82, fig. 4 .

Globigerinoides sacculifer (Brady) Bé, 1967, fig. 6a.

Rare and sporadic in all Quaternary sequences.

\section{Globigerinoides tenellus Parker}

(Plate 4, Figs. 6-7)

Globigerinoides tenellus Parker, 1958, pl. 6, figs. 7-11.

This small species is very similar to Globigerina rubescens but differs in the presence of the supplementary aperture on the spiral side. It occurs in minor abundances. Taking into account its scarcity, we have added this species to $G$. rubescens ( $G$. rubescens group) in the statistics.

\section{Globigerinoides trilobus (Reuss)}

(Plate 4, Figs. 8-9)

Globigerina triloba Reuss, 1850 , p. 374 , pl. 47 , fig. 11

This form associated by some workers with the sacculifer forma either as sacculifer species (Bé, 1977) or as "trilobus" species (Cifelli, 1965 ) is considered here as a distinct species. It occurs often in the same sample as $G$. sacculifer does, but it is more common.

\section{Genus GLOBOROTALIA Cushman, 1927 Globorotalia crassaformis (Galloway and Wissler) (Plate 5, Figs. 1-4, 9-10)}

Globigerina crassaformis Galloway and Wissler, 1927, p. 41, pl. 7, figs. $12 \mathrm{a}-\mathrm{c}$.

Globigerina crassaformis crassaformis (Galloway and Wissler) Rögl, 1974 , p. 763 , pl. 3 , figs. $1-5$.

No distinction is made in this broad group. It is scarce to common in the lower Quaternary, but its frequency decreases from the top of Subzone C.

\section{Globorotalia viola Blow}

(Plate 5, Figs. 5-8)

Globorotalia (Globorotalia) crassula viola Blow, 1969, pp. 397-398, pl. 5, figs. 4-9. 
This form seems to be an ecological variation of Globorotalia crassula sensu Berggren (1977). Its occurrence is the same. This illustrated form is added to $G$. crassula in the statistics.

\section{Globorotalia crassula Cushman and Stewart (Plate 5, Figs. 11-12)}

Globorotalia crassula Cushman and Stewart, 1930, p. 77, pl. 7, fig. 1; Blow, 1969, p. 361, pl. 9, figs. 1-3 (holotype refigured).

This form disappears at the top of Subzone E. It is common and typical in the uppermost Pliocene.

\section{Globorotalia hirsuta (d'Orbigny)}

(Plate 6, Figs. 1-2)

Rotalina hirsuta d'Orbigny, 1839, p. 131, pl. 2, figs. 37-39.

Globorotalia hirsuta (d'Orbigny) Parker, 1962, p. 236, pl. 5, figs. 10-15; Bé, 1967, fig. 27a-c.

This species seems to have a short occurrence in the Quaternary. Its appearance is noted at the LAD of Pseudoemiliania lacunosa, as in the North Atlantic. Future analyses should confirm this fact. In Site 517 , its frequency increases in the upper part of Subzone A. This fact may be compared to the occurrence shown by Williams and Ledbetter (1979) from about 240,000 yr. ago.

\section{Globorotalia inflata (d'Orbigny)}

(Plate 6, Figs. 3-4)

Globigerina inflata d'Orbigny, 1839, p. 134, pl. 2, figs. 7-9.

Globorotalia inflata (d'Orbigny) Parker, 1962, p. 236, pl. 5, figs. 6-9; Bé, 1967, fig. 24.

This species is common to abundant from the Subzone E to the middle part of the Subzone C. Its frequency does not vary considerably. Above Subzone C, the frequency becomes common with some variations. We treat $G$. inflata as belonging to the temperate zones with significant preference for high nutrient concentration.

\section{Globorotalia menardii (d'Orbigny)}

(Plate 6, Figs. 5-6)

Rotalia menardii d'Orbigny, 1826 , modèle no. 10 , unpublished plate, pl. 11 , fig. 1 .

Globorotalia menardii (d'Orbigny) Le Calvez, 1977, pp. 109-110, figs. 1-2.

Always rare, this species is less sporadic in the upper part of the Quaternary sequence.

\section{Globorotalia scitula (Brady)}

(Plate 6, Fig. 7-10)

Pulvinulina scitula Brady, 1882, pp. 716-717; Banner and Blow, 1960, p. 27 , pl. 5 , fig. 5 (lectotype).

Globorotalia scitula (Brady) Parker, 1962, p. 238, pl. 6, figs. 4-6; Bé, 1967, fig. 28.

In this population we accept Globorotalia bermudezi as a term of the specific variation in the $G$. scitula species. It is rare to common. Its frequency increases in Subzone A.

\section{Globorotalia triangula Theyer}

(Plate 7, Figs. 1-2)

Globorotalia inflata triangula Theyer, 1973, pp. 200-201, pl. 1, figs. $1-7$.

Very few specimens are observed in Subzone E.

\section{Globorotalia truncatulinoides (d'Orbigny)}

(Plate 7, Figs. 3-4)

Rotalia truncatulinoides d'Orbigny, 1839a, p. 132, pl. 2, figs. 25-27. Globorotalia truncatulinoides (d'Orbigny) Bé, 1967, fig. 24.

This species is common in this section. Its coiling direction is often random. But we can observe few right-coiling pulsations regarded as a modification of the hydrologic setting during the Quaternary.

\section{Globorotalia tumida (Brady)}

(Plate 7, Figs. 5-6)

Pulvinulina menardii (d'Orbigny) var. tumida Brady, 1877 , p. 535; Brady, 1884, p. 692, pl. 103, figs. 4-6; Banner and Blow, 1960, p. 26, pl. 5, fig. 1 (lectotype).
Globorotalia tumida (Brady) Parker, 1962, p. 239, pl. 6, figs. 8-10. This rare species is added to Globorotalia menardii in our statistics.

\section{Genus HASTIGERINA \\ Hastigerina siphonifera (d'Orbigny) \\ (Plate 7, Fig. 7)}

Globigerina siphonifera d'Orbigny, 1839, pl. 4, figs. 15-18.

Globigerinella aequilateralis (Brady) Bé, 1967, fig. 16.

Hastigerina siphonifera (d'Orbigny) Loeblich and Tappan, 1964, fig. 531,1; Le Calvez, 1977, pp. 33-34, fig. 6.

Rare to scarce in all sections.

\section{Genus ORBULINA}

Orbulina universa d'Orbigny

(Plate 7, Fig. 8)

Orbulina universa d’Orbigny, 1839b, p. 3, fig. 1; Bé, 1967, fig. 3a. Rare to low occurrence.

\section{Genus PULLENIATINA}

Pulleniatina obliquiloculata (Parker and Jones)

(Plate 7, Figs. 9-10)

Pullenia sphaeroides (d'Orbigny) var, obliquiloculata Parker and Jones, 1865 , pp. 365,368 pl. 19, figs. $4 \mathrm{a}-\mathrm{b}$; Banner and Blow, 1960 , p. 25 , pl. 7 , fig. 4 (lectotype).

Pulleniatina obliquiloculata (Parker and Jones) Parker, 1962, p. 234, pl. 4, figs. 13-16, 19, 22; Bé, 1967, Fig. 23.

Very rare specimens in the lower Quaternary (Subzones C, D, E).

\section{Genus SPHAEROIDINELLA}

Sphaeroidinella dehiscens (Parker and Jones)

(Plate 7, Fig. 11)

Sphaeroidina bulloides d'Orbigny var. dehiscens Parker and Jones, 1865 , p. 369 , pl. 19 fig. 5; Banner and Blow, 1960, p. 35, pl. 7, fig. 3 (lectotype).

Sphaeroidinella dehiscens (Parker and Jones) Parker, 1962, p. 234, pl. 5, figs. 1-2; Bé, 1967, fig. 7a-c.

Rare specimens occur in Subzones C to E.

\section{Genus GLOBOROTALOIDES \\ Globorotaloides hexagona (Natland)}

Globigerina hexagona Natland, 1938, p. 149, pl. 7, figs. 1a-c.

This species is present sporadically from Subzone C to the top of Site 517. It disappears at the beginning of the last glacial in the Atlantic province.

\section{ACKNOWLEDGMENTS}

The writers wish to thank the Deep Sea Drilling Project for having invited one of them (C. P.) to participate in the Glomar Challenger southwestern Atlantic Leg 72. The Institut de Géologie du Bassin d'Aquitaine provided laboratory facilities and technical help. The scanning electron micrographs were taken by Ms. Le Blanc at the University of Bordeaux. The authors wish to express their thanks to Colette Vergnaud Grazzini for helpful discussions and to William Coulbourn, Dave Johnson, and Norman Hamilton for careful reviews of the manuscript.

\section{REFERENCES}

Banner, F. T., and Blow, W. H., 1960. Some primary types of species belonging to the superfamily Globigerinaceae. Contrib. Cushman Found. Foraminiferal Res., 11(1):1-41.

Bé, A. W. H., 1967. Foraminifera families: Globigerinidae and Globortaliidae. Fiche No. 108. In Fraser, J. H. (Ed.), Fiches d'Identification du Zooplancton: Charlottenlund, Denmark (Conseil international pour l'exploration de la mer).

1977. An ecological, zoogeographic and taxonomic review of recent foraminifera. In Ramsay, A. T. S. (Ed.), Oceanic Micropaleontology (Vol. 1): New York (Academic Press), 1-100.

Bé, A. W. H., and Tolderlund, D. S., 1971. Distribution and ecology of living planktonic foraminifera in surface waters of the Atlantic 
and Indian Oceans. In Funnell, B. M., and Riedel, W. R., (Eds.), The Micropaleontology of Oceans: New York (Cambridge University Press), pp. 105-149.

Berggren, W. A., 1969. Rates of evolution in some Cenozoic planktonic foraminifera. Micropaleontology, 15:351-365.

1977. Late Neogene planktonic foraminiferal biostratigraphy of the Rio Grande Rise (South Atlantic). Mar. Micropaleontol., 2:265-313.

Berggren, W. A., Burckle, L. H., Cita, M. B., Cooke, H. B. S., Funnell, B. M., Gartner, S., Hays, J. D., Kennett, J. P., Opdyke, N. D., Pastouret, L., Shackleton, N. J., and Takayanagi, Y., 1980. Towards a Quaternary time scale. Quat. Res., 13:277-302.

Blow, W. H., 1959. Age, correlation and biostratigraphy of the upper Tocuyo (San Lorenzo) and Pozon formations, eastern Falcon, Venezuela. Bull. Am. Paleontol., 39:67-251.

1969. Late middle Eocene to Recent planktonic foraminiferal biostratigraphy. In Bronniman, P., and Renz, H. H. (Eds.), Proc. First Int. Conf. Plankt. Microfossils: Leiden (E. J. Brill), 1:199-422.

Bolli, H. M., and Premoli Silva, I., 1973. Oligocene to Recent planktonic foraminifera and stratigraphy of the Leg 15 sites in the Caribbean Sea. In Edgar, N. T., Saunders, J. B., et al., Init. Repts. DSDP, 15: Washington (U.S. Govt. Printing Office), 475-497.

Boltovskoy, E., 1968. Living planktonic foraminifera of the eastern part of the tropical Atlantic. Rev. Micropaleontol., 11:85-98.

1970. Masas de Agua (caracteristica, distribución, movimientos) en la superficie del Atlantico sudoeste según indicatores biológicos foraminiferos. Argent. Serv. Hidr. Nav., 2(643):5-99.

1973. Estudio de testigos submarinos del Atlántico sudoccidental. Rev. Mus. Argent. Cienc. Nat. Bernardino Rivadavia, 7(4):215-347.

1976. Distribution of recent foraminifera of the South American region. In Hedley, R. H., and Adams, G. C. (Eds.), Foraminifera: New York (Academic Press), pp. 171-236.

Brady, H. B., 1877. Supplementary note on the foraminifera of the chalk (?) of the New Britain Group. Geol. Mag., N.S., Decade 2(4):534-536.

1879. Notes on some of the reticularian Rhizopoda of the Challenger Expedition. Q. J. Microsc. Sci., 19:20-26 and 261-299. 1882. Report on the foraminifera. In Tizard, J., and Murray, J. (Eds.), Exploration on the Faröe Channel, during the summer of 1880, in H.M.S. "Knight Errant," with subsidiary reports. R. Soc. Edinburgh Proc., 11:708-717.

1884. Report on the foraminifera dredged by H.M.S. Challenger during the years 1873-1876. Report on the Scientific Results of the Voyage of the H.M.S. Challenger during the Years 18731876, Zoology (Vol. 9, pt. 22).

Cifelli, R., 1965. Planktonic foraminifera from the western North Atlantic. Smithson. Misc. Collect., 148(4), 4599:1-36.

1971. On the temperature relationships of planktonic foraminifera. J. Foraminiferal Res., 1:170-177.

Cifelli, R., and Smith, R. K., 1970. Distribution of planktonic foraminifera in the vicinity of the North Atlantic Current. Smithson. Contrib. Paleobiol., 4:1-52.

Climap Project Members, 1976. The surface of the ice-age earth. Science, 191(4232):1131-1137.

Cushman, J. A., Stewart, R. E., and Stewart, K. C., 1930. Tertiary foraminifera from Humboldt County, California. San Diego Soc. Nat. Hist. Trans., 6:41-49.

Egger, J. G., 1893. Foraminiferen aus Meeresgrundproben, gelothet von 1874 bis 1876 von S.M. Sch. Gazelle. Abh. Bayer. Akad. Wiss. Math.-Phys. Kl., 18:195-458.

Ehrenberg, C. G., 1861. Elemente des tiefen Meeresgründes im Mexikanischen Golfstrome bei Florida, über die Tiefgründe. Verhältnisse des Oceans am Eingange der Davisstrasse und bei Island. Monatsber. K. Preuss. Akad. Wiss. Berlin, Phys., pp. 222-240 and 275-315.

1872. Mikrogeologische Studien als Zusammenfassung seiner Beobachtungen des kleinsten Lebens der Meeres. Tiefgründe alter Zonen und dessen geologischen Einfluss. Abh. K. Akad. Wiss. Berlin, Phys., pp. 265-322.

Emiliani, C., 1955. Pleistocene temperatures. J. Geol., 63:538-578. 1966. Paleotemperature analysis of Caribbean cores P6304

8 and P6304-9 and a generalised temperature curve for the last 425,000 years. J. Geol., 74:109-126.
Galloway, J. J., and Wissler, S. G., 1927. Pleistocene foraminifera from the Lomita Quarry, Palos Verdes Hills, California. J. Paleontol., 1:35-87.

Hedberg, H. D., 1972. Introduction to an international guide to stratigraphic classification terminology and usage. Lethaia, 5:285-295.

Hofker, J., 1956. Tertiary foraminifera of coastal Ecuador, Pt. 2Additional notes on the Eocene species. J. Paleontol., 30:891-958.

Huang, T. C., and Watkins, N. D., 1977. Contrast between the Brunhes-Matuyama sedimentary records of bottom water activity in the South Pacific. Mar. Geol., 23:113-132.

Johnson, D. A., Ledbetter, M., and Burckle, L. H., 1977. Vema Channel paleooceanography: Pleistocene dissolution cycles and episodic bottom water flow. Mar. Geol., 23:1-33.

Kennett, J. P., 1970. Pleistocene paleoclimates and foraminiferal biostratigraphy in subantarctic deep sea cores. Deep-Sea Res., 17: 305-318.

Kipp, N. G., 1976. New transfer function for estimating past sea-surface conditions from sea-bed distribution of planktonic foraminiferal assemblages in the North Atlantic. Bull. Geol. Soc. Am., 145: 3-41.

Krasheninnikov, V. A., 1979. Stratigraphy by means of planktonic foraminifers of Neogene and Quaternary sediments near the crest of the Mid-Atlantic Ridge, DSDP Sites 395 and 396. In Melson, W. G., Rabinowitz, P. D., et al., Init. Repts. DSDP, 45: Washington (U.S. Govt. Printing Office) 319-322.

Lamb, J. L., and Beard, J. H., 1972. Late Neogene planktonic foraminifers in the Caribbean, Gulf of Mexico, and Italian stratotypes. Kans. Univ. Paleontol. Contrib., 57:1-67.

Le Calvez, Y., 1977. Révision des foraminifères de la collection d'Orbigny. II-Foraminifères de l'Ile de Cuba. Cah. Micropaléontologie, CNRS Paris.

Ledbetter, M. T., 1979. Fluctuations of Antarctic bottom water velocity in the Vema Channel during the last 160,000 years. Mar. Geol., 33:71-89.

Ledbetter, M. T., and Johnson, D. A., 1976. Intensified flow of Antarctic bottom water through the Vema Channel during the last ice age. Science, 194:837-839.

Lena, H., and Watanabe, S., 1981. Foraminiferos planctonicos como indicatores hidrológicos de tres curceros oceanográficas en el Atlántico sudoccidental. Rev. Esp. Micropaleontol., 13:61-68.

Loeblich, A. R., and Tappan, H., 1964. Protistata 2, Sarcodina Chiefly "Thecamoebiens" and foraminiferida, 1 and 2. In Moore, R. C. (Ed.), Treatise on Invertebrate Paleontology (Part C): New York (Geol. Soc. Am.), pp. C511-C 900 .

Malmgren, B., and Kennett, J. P., 1977. Biometric differentiation between recent Globigerina bulloides and Globigerina falconensis in the southern Indian Ocean. J. Foraminiferal Res., 7:130-148.

Natland, M. L., 1938. New species of foraminifera from off the west coast of north America and from the later Tertiary of the Los Angeles Basin. Scripps Inst. Oceanogr. Bull. Tech. Ser., 4:137-164.

d'Orbigny, A. D., 1826. Tableau méthodique de la classe des Cephalopodes. Ann. Sci. Nat., Ser. 1, 7:96-314.

1839a. Foraminifères des Iles Canaries. In Barker-Webb, P., and Berthelot, S. (Eds.), Histoire Naturelle des Iles Canaries, 2:119-146.

1839b. Foraminifères. In de la Sagra, R. (Ed.), Histoire Physique, Politique et Naturelle de l'Ile de Cuba, 8:1-224.

Parker, F. L., 1958. Eastern Mediterranean Foraminifera. Rep. Swed. Dep-Sea Exped., 8:217-283.

1962. Planktonic foraminiferal species in Pacific sediments. Micropaleontology, 8:219-254.

Parker, W. K., and Jones, T. R., 1865. On some foraminifera from the North Atlantic and Arctic Oceans, including Davis Straits and Baffin's Bay. Phil. Trans. R. Soc. London, 155:325-441.

Pflaumann, U., and Krasheninnikov, V. A., 1978. Quaternary stratigraphy and planktonic foraminifers of the eastern Atlantic. Deep Sea Sea Drilling Project, Leg 41. In Lancelot, Y., Siebold, E., et al., Init. Repts. DSDP, Suppl. to Vol. 38, 39, 40, and 41: Washington (U.S. Govt. Printing Office), 883-911.

Pujol, C., 1975. Intérêt des variations du sens d'enroulement de $G$. truncatulinoides et de G. hirsuta du Golfe de Gascogne. Rev. Esp. Micropaleontol., Num. Spec., pp. 107-116.

1980. Les foraminifères planctoniques de l'Atlantique nord au Quaternaire. Ecologie, Stratigraphie, Environnement. Mem. Inst. Géol. Bassin d'Aquitaine, 10. 
1981. Planktonic foraminifera in biostratigraphy. Modelisation of biozonation in a Quaternary model. Int. Symp. Concept., Meth. Paleontol. Barcelona, pp. 209-221.

Pujol, C., and Duprat, J., 1977. Interest of Globorotalia hirsuta in the Quaternary of the northeastern Atlantic. 5e Réunion Annuelle des Sciences de la Terre, Abstract: 397.

Reid, J. L., Nowlin, W. D., and Patzert, W. C., 1977. On the characteristics and circulation of the southwestern Atlantic ocean. $J$. Phys. Oceanogr., 7:62-91.

Reuss, A. E., 1850. Neues foraminiferen aus den Schichten des österreichischen Tertiärbeckens. Denkschr. K. Akad. Wiss. Wien, Math. Naturw. K., 1:365-390.

Rögl, F., 1974. The evolution of the Globorotalia truncatulinoides and Globorotalia crassaformis group in the Pliocene and Pleistocene of the Timor Trough, DSDP Leg 27, Site 262. In Veevers, J. J., Heirtzler, J. R., et al. Init. Repts. DSDP, 27: Washington (U.S. Govt. Printing Office), 743-767.

Shackleton, N. J., and Opdyke, N. D., 1973. Oxygen isotope and palaeomagnetic stratigraphy of Equatorial Pacific core V 28-238: oxygen isotope temperatures and ice volumes on a $10^{5}$ and $10^{6}$ year scale. Quat. Res., 3:39-55.
1976. Oxygen isotope and palaeomagnetic stratigraphy of Equatorial Pacific core V 28-239, late Pliocene to latest Pleistocene. In Cline, R. M., and Hays, J. D., (Eds.), Investigation of Late Quaternary Paleoceanography and Paleoclimatology: Boulder, CO (Geol. Soc. Am. Mem.), 145:449-464.

Theyer, F., 1973. Globorotalia inflata triangula, a new planktonic foraminiferal subspecies. J. Foraminiferal Res., 3:199-201.

Thierstein, H. R., Geitzenauer, K. R., Molfino, B., and Shackleton, N. J., 1977. Global synchroncity of late Quaternary coccolith datum levels: validation by oxygen isotopes. Geology, 5:400-404.

Van Donk, J., 1976. $\mathrm{O}^{18}$ record of the Atlantic Ocean for the entire Pleistocene Epoch. Bull. Geol. Soc. Am., 145:147-163.

Williams, D. F., and Ledbetter, M. T., 1979. Chronology of late Brunhes biostratigraphy and late Cenozoic disconformities in the Vema Channel (South Atlantic). Mar. Micropaleontol., 4:125-136.

Zobel, B., 1968. Phänotypische varianten von Globigerina dutertrei d'Orbigny (foram.), ihre bedeutung für die stratigraphie in quartären Tiefse-Sedimenten. Geol. Jahrb., 85:97-122.

Date of Initial Receipt: April 6, 1982 

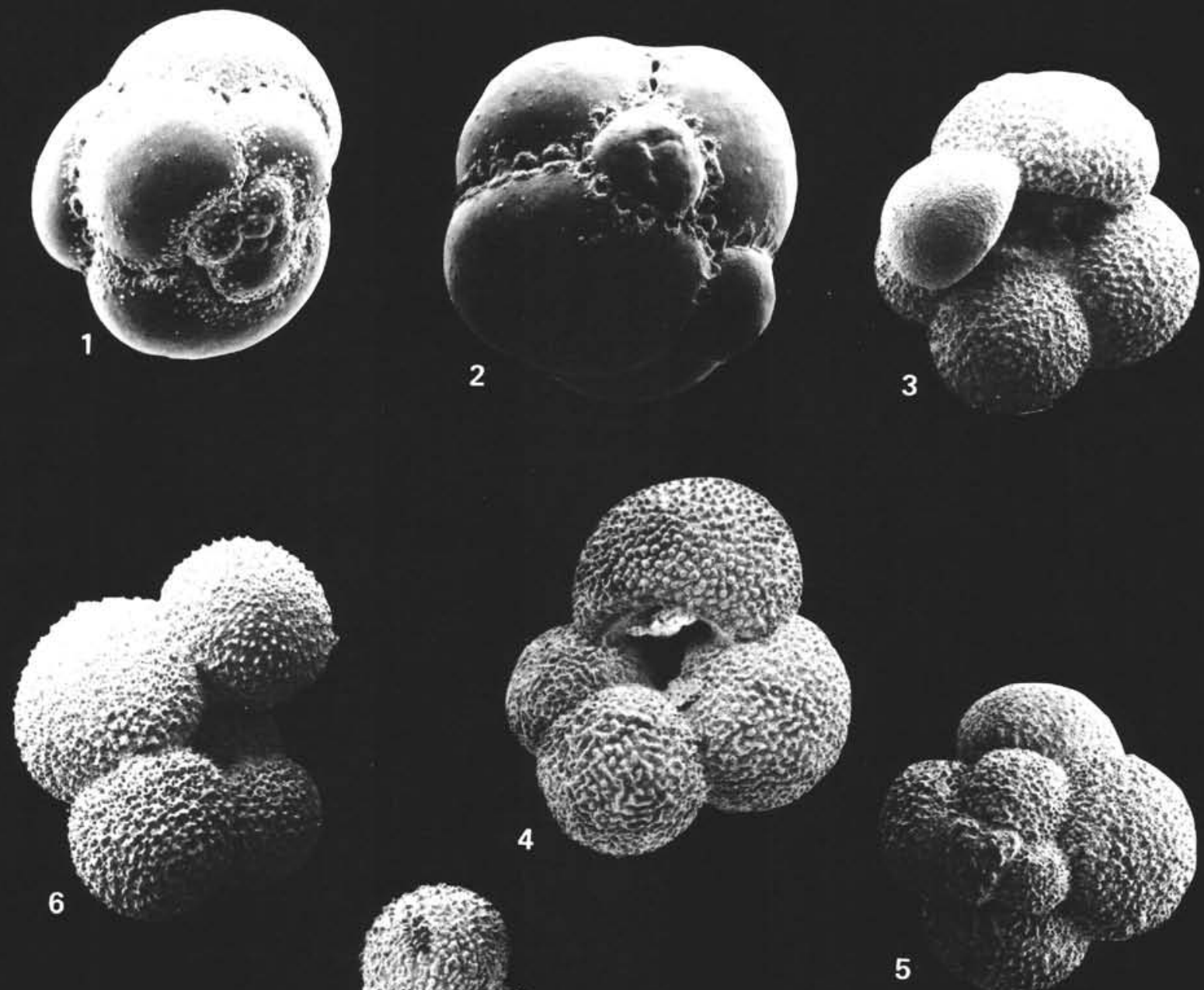

8
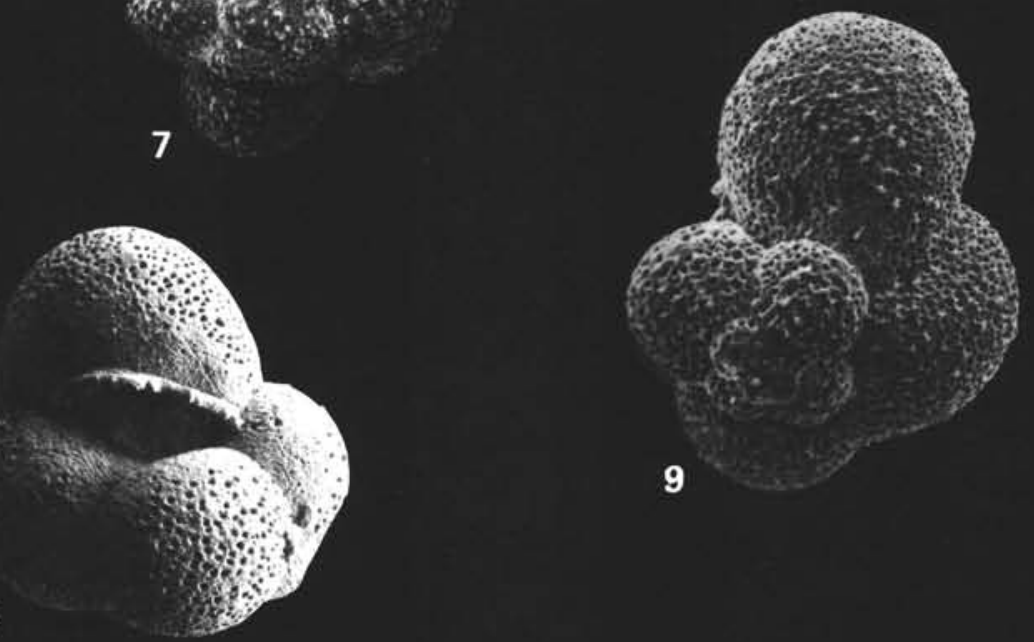

Plate 1. (Specimens magnified $\times 120$ unless otherwise indicated.) $1-2$. Candeina nitida d'Orbigny, Sample $517-1-1,0-2.5 \mathrm{~cm}, \times 80,(1)$ spiral view, (2) umbilical view. 3-5. Globigerina bulloides d'Orbigny, (3) Sample 517-3-1, $40 \mathrm{~cm}$, umbilical view, $\times 100$, (4) Sample 517-3,CC, umbilical view, (5) Sample 517-3-1, $40 \mathrm{~cm}$, spiral view. 6-7. G. calida Parker, Sample 517-1-1, 0-2.5 cm, $\times 100,(6)$ umbilical view, (7) spiral view, 8-9. G. digitata Brady, Sample 517-4-2, $50 \mathrm{~cm}$, (8) umbilical view, (9) spiral view. 

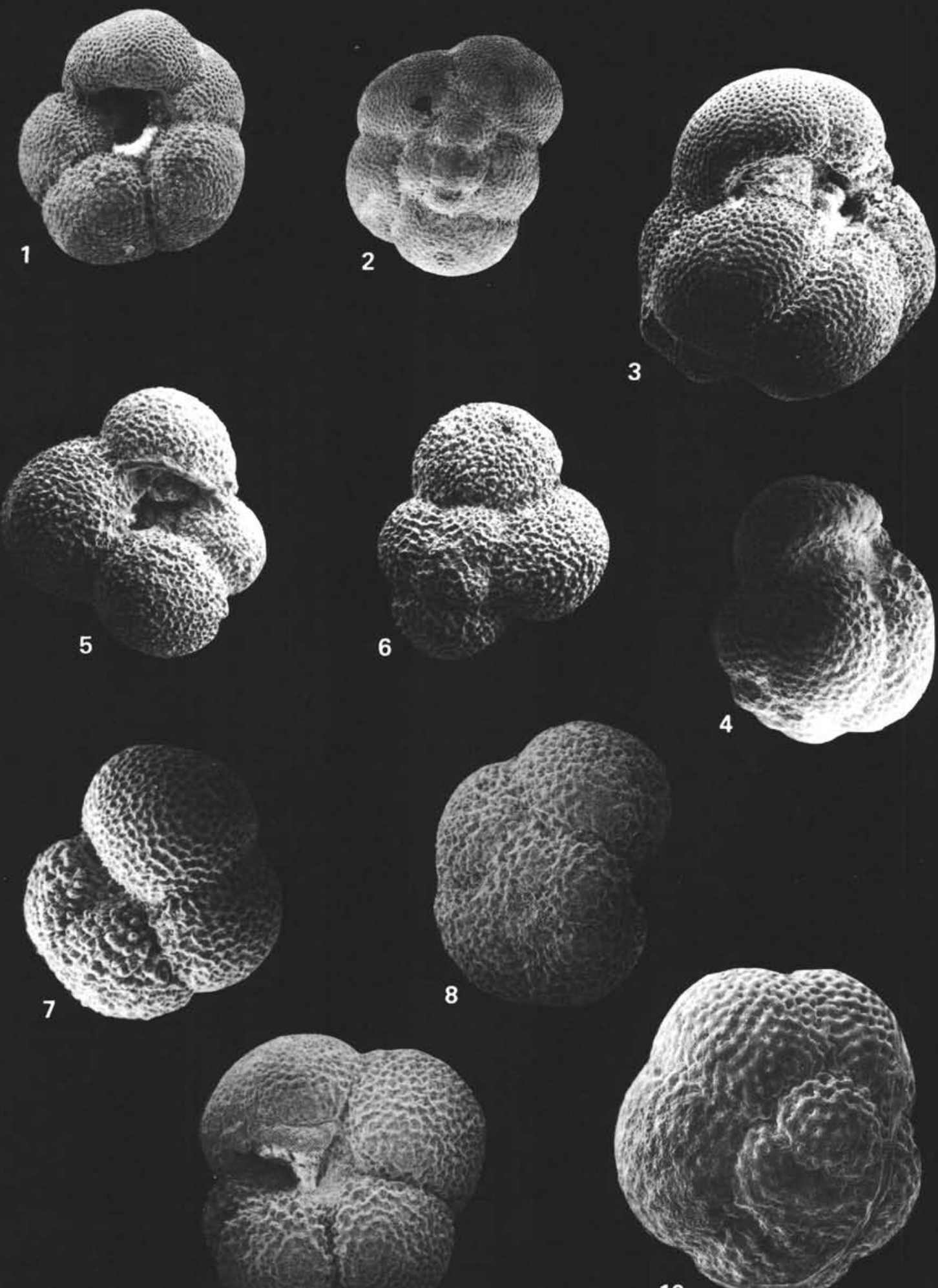

9

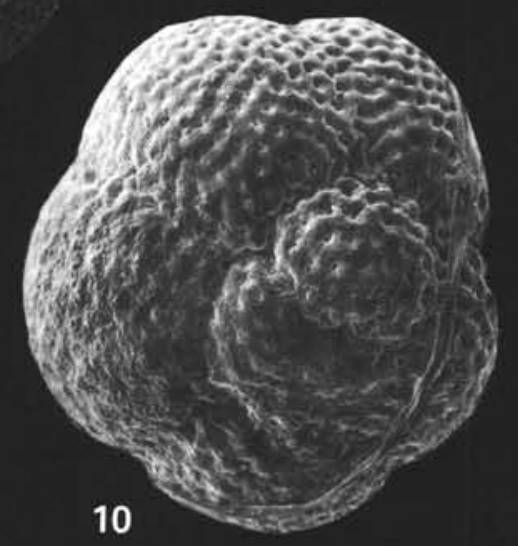

Plate 2. (Specimens magnified $\times 120$ unless otherwise indicated.) 1-4. Globigerina eggeri Zobel, (1-2) Sample $517-7-1,10 \mathrm{~cm}, \times 60,(1$, umbilical view; 2, spiral view), (3-4) Sample $517-7-1,50 \mathrm{~cm},(3$, umbilical view, $\times 80 ; 4$, peripheral view, $\times 60)$. 5-6. G. falconensis Blow, Sample 517-3,CC, (5) umbilical view, (6) spiral view. 7-10. G. pachyderma (Ehrenberg), (7) Sample 517-1,CC, umbilical view, (8) Sample 517-2-1, 0-2.5 cm, spiral view, $\times 140$, (9) Sample 517-2-1, 0-2.5 cm, umbilical view, (10) Sample 517-1-1, 0-2.5 cm, spiral view, $\times 140$. 

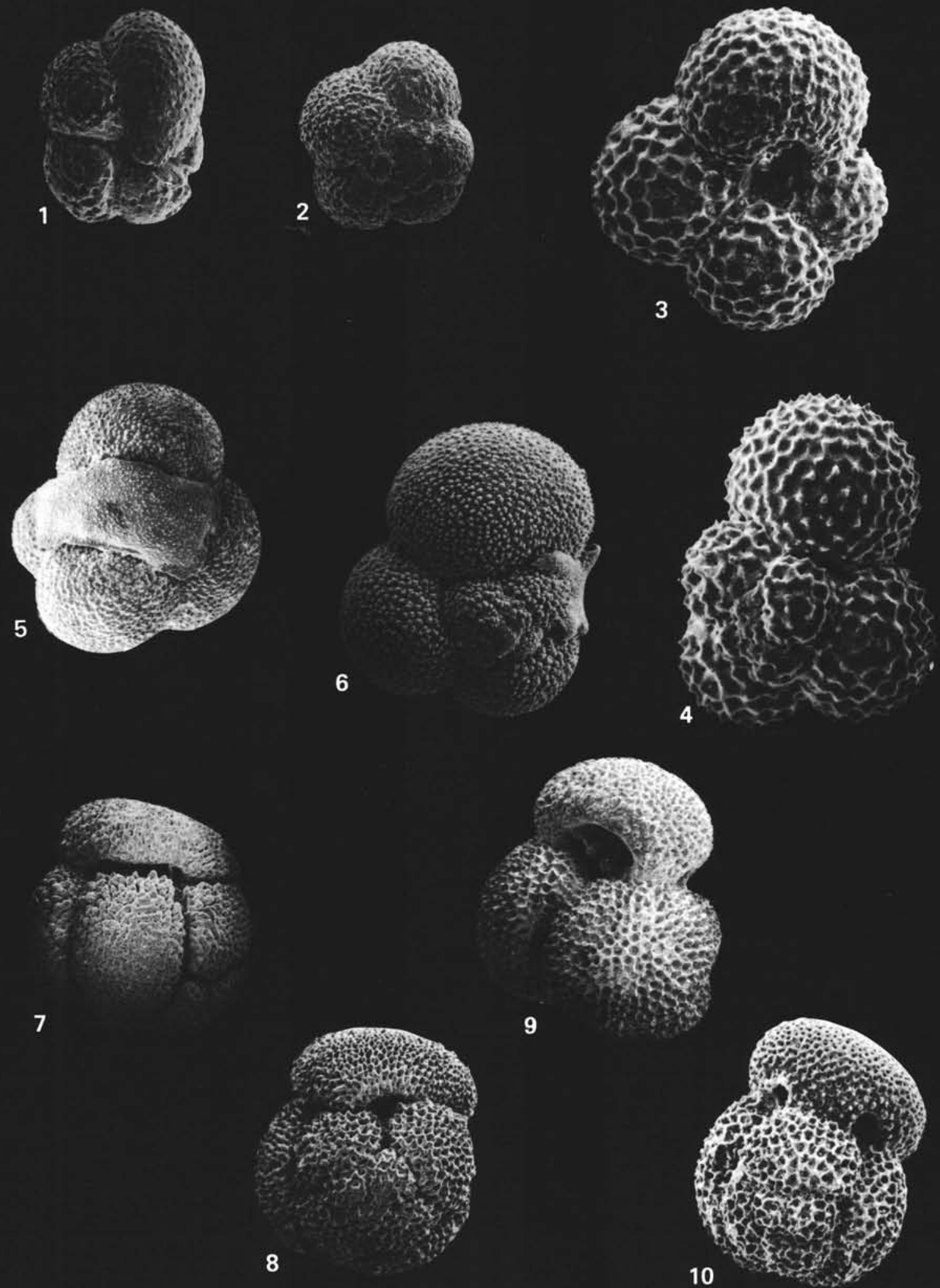

Plate 3. 1-2. Globigerina quinqueloba Natland, Sample $517-1, C C, \times 180$, (1) umbilical view, (2) spiral view. 3-4. G. rubescens Hofker, Sample 517-1-1, 0-2.5 cm, $\times 200$, (3) umbilical view, (4) spiral view. 5-6. Globigerinita glutinata (Egger), Sample 517-1-1, 0-2.5 cm, $\times 160,(5)$ umbilical view; (6) spiral view. 7-8. Globigerinoides conglobatus (Brady), Sample 517-1-1, 0-2.5 cm, (7) umbilical view, $\times 60$, (8) spiral view, $\times 80$. 9-10. G. ruber (d'Orbigny) white variety, Sample $517-1-1,0-2.5 \mathrm{~cm}, \times 100$, (9) umbilical view, (10) spiral view. 

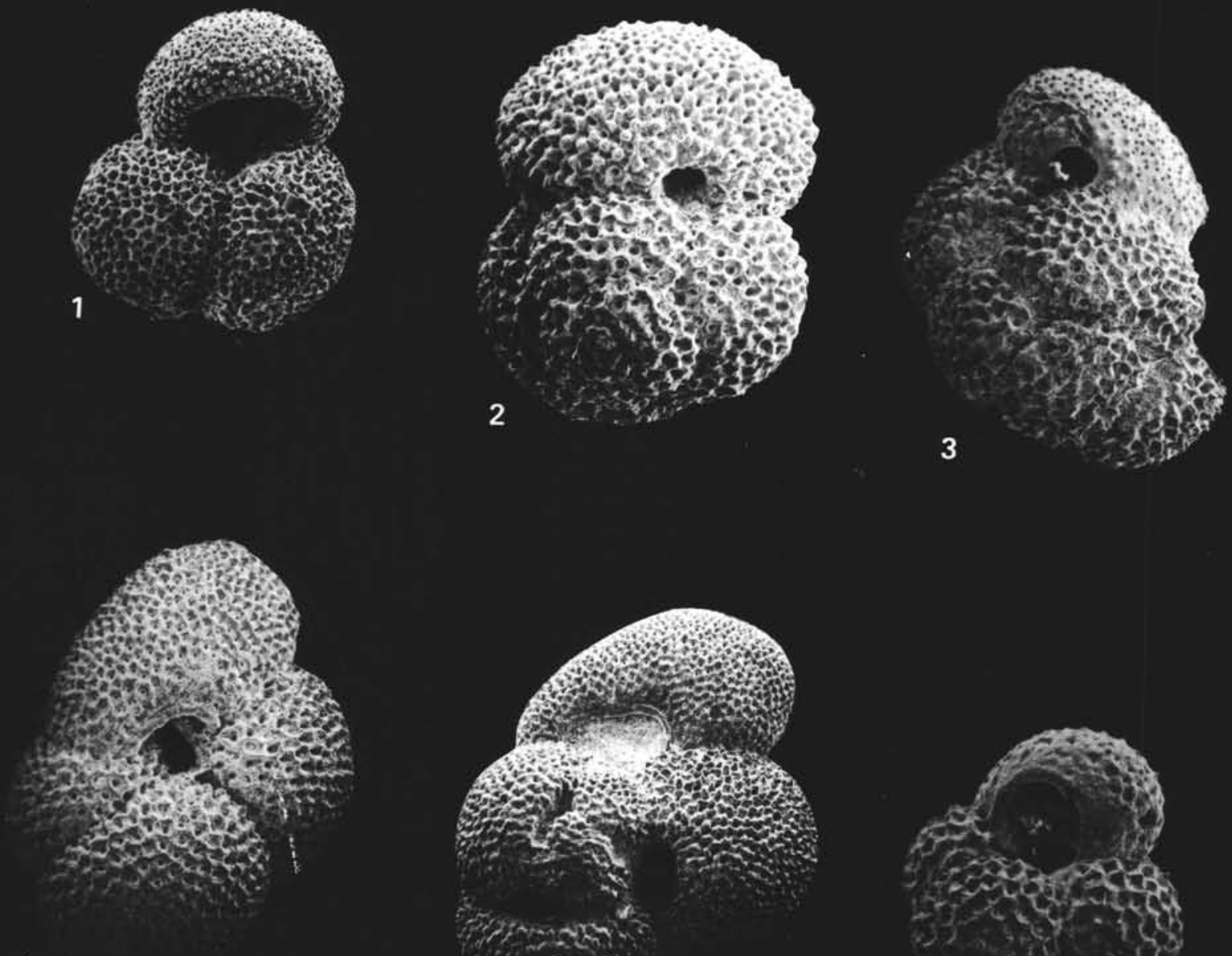

4

5

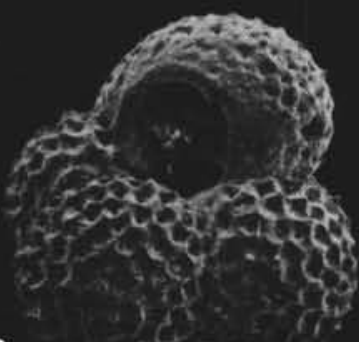

6
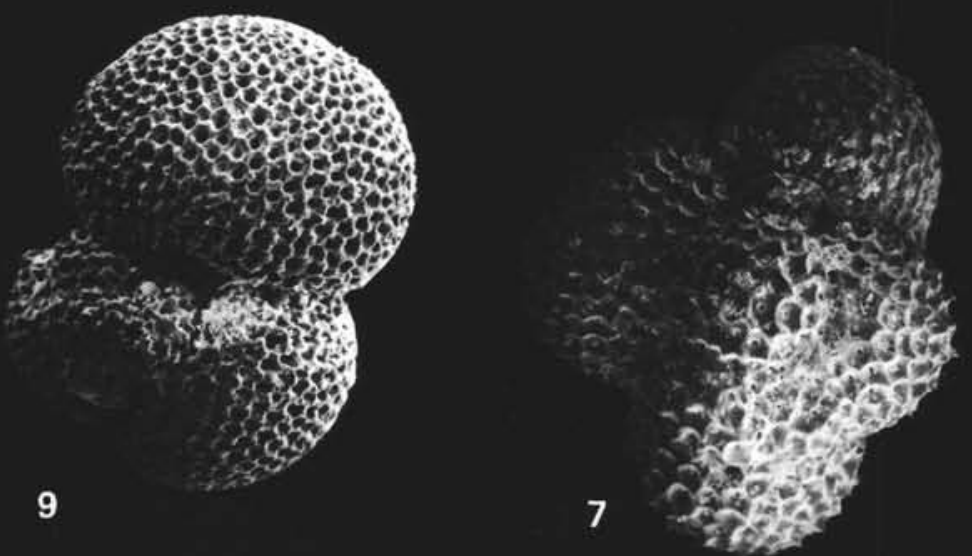

Plate 4. (Specimens magnified $\times 80$ unless otherwise indicated.) 1-2. Globigerinoides ruber (d'Orbigny) pink variety, (1) Sample 517-1-1, 0-2.5 $\mathrm{cm}$, umbilical view, (2) Sample $517-1-2,10 \mathrm{~cm}, \times 120$, spiral view. 3. G. ruber (d'Orbigny) pyramidilis, Sample $517-4-2,50 \mathrm{~cm}, \times 20$, spiral view. 4-5. G. sacculifer (Brady), Sample 517-1-2, $10 \mathrm{~cm}$, (4) umbilical view, (5) spiral view, $\times 60$. 6-7. G. tenellus Parker, Sample 517-1-1, 0-2.5 cm, $\times 160$, (6) umbilical view, (7) spiral view. 8-9. G. trilobus (Reuss), Sample 517-1-1, 0-2.5 cm, (8) umbilical view, $\times 100$, (9) spiral view. 


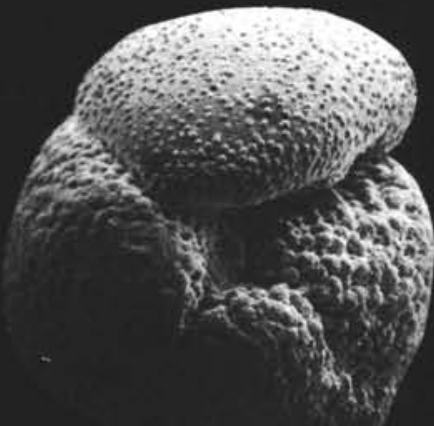

1

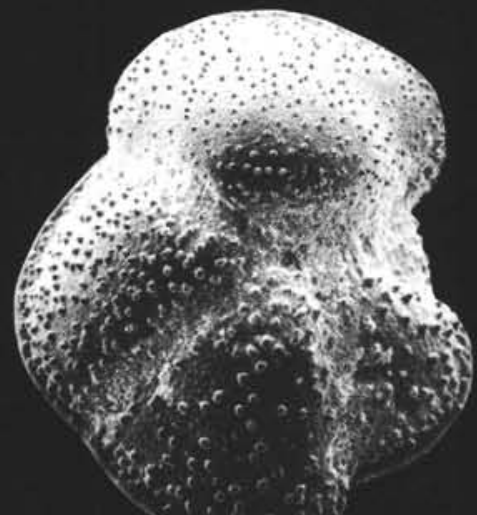

5
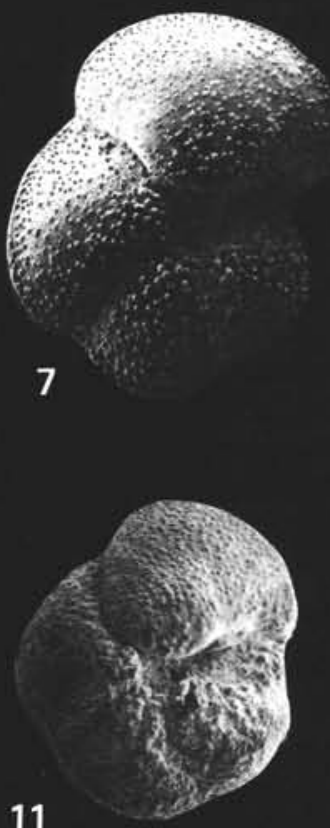

11
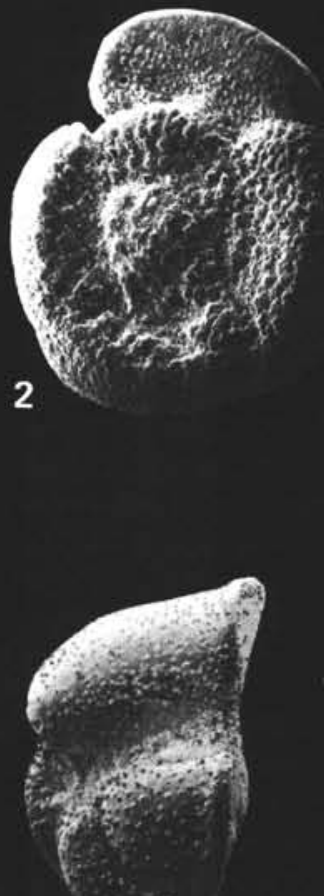

6

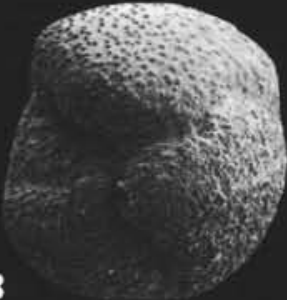

3

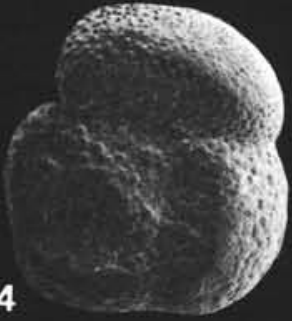

4

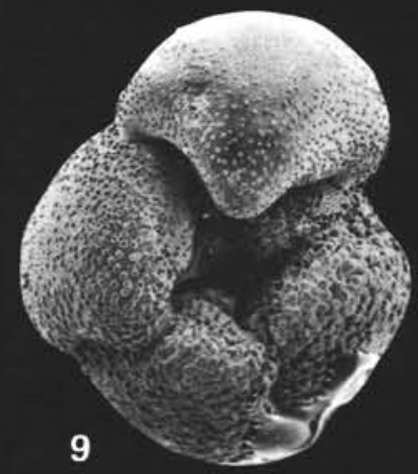

8
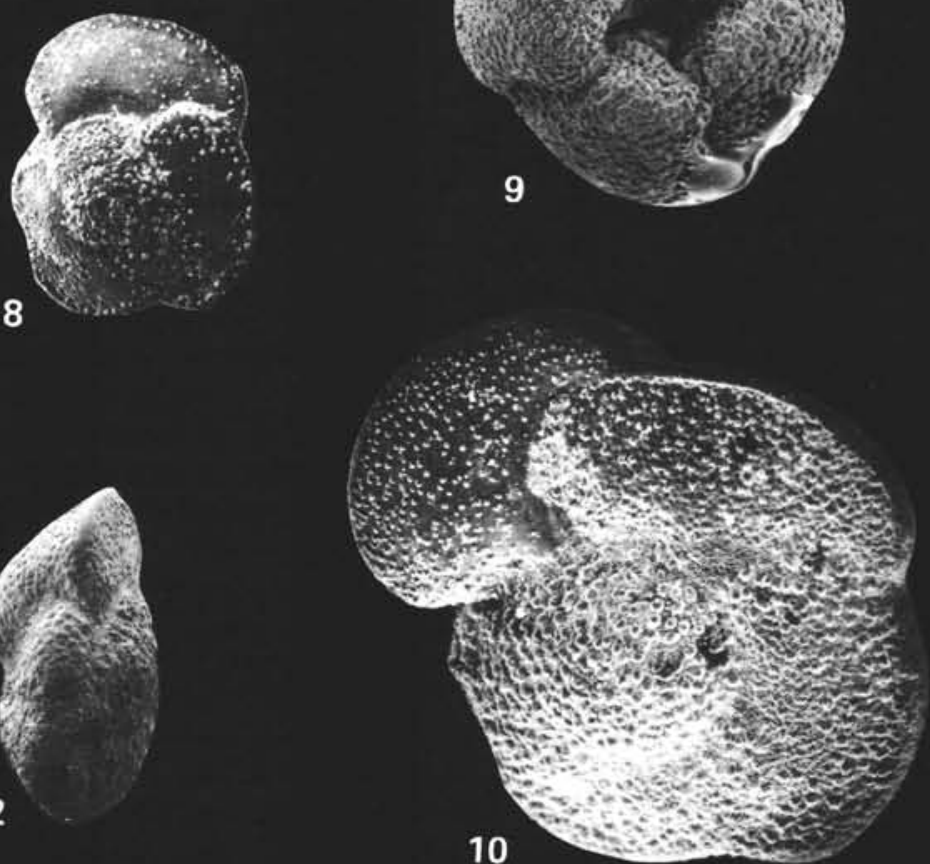

Plate 5. (Specimens magnified $\times 60$ unless otherwise indicated.) 1-4. Globorotalia crassaformis (Galloway and Wissler), (1-2) Sample 517-7-3, $50 \mathrm{~cm}$, (1, umbilical view, $\times 80 ; 2$, spiral view), (3-4) Sample 517-6,CC, (3, umbilical view; 4, spiral view). 5-8. G. viola Blow, Sample 517-7-1, $50 \mathrm{~cm}$, (5) umbilical view, $\times 80$, (6) peripheral view, (7) umbilical view, (8) spiral view. 9-10. G. crassaformis (Galloway and Wissler), (9) Sample 516-6,CC, umbilical view, (10) Sample 517-7-1, $50 \mathrm{~cm}$, spiral view, $\times 80$. 11-12. G. crassula Cushman and Stewart, Sample 517-7-1, 50 cm, (11) umbilical view, (12) peripheral view. 


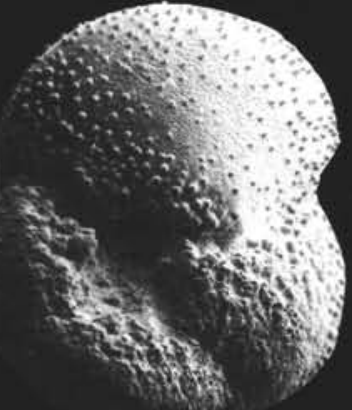

1

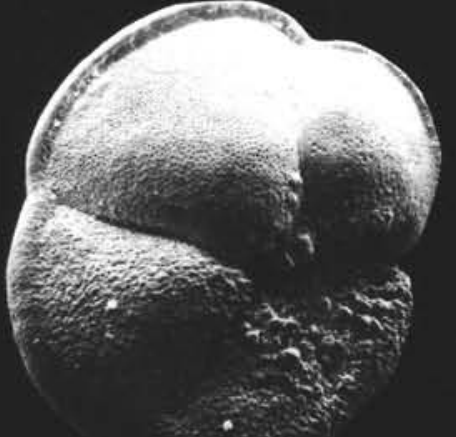

5

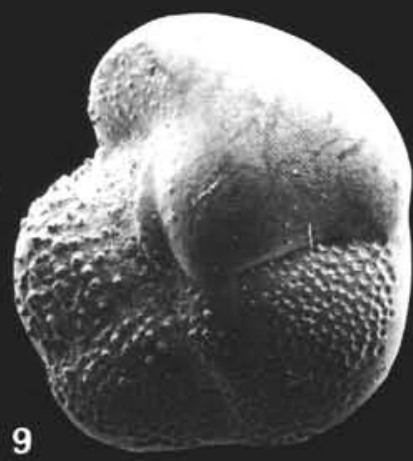

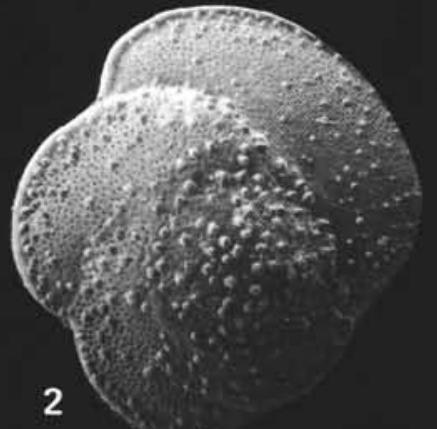

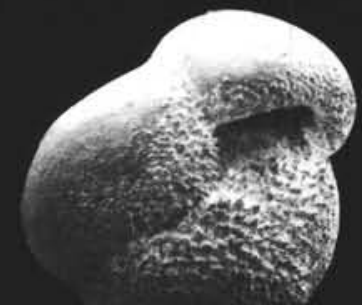

3
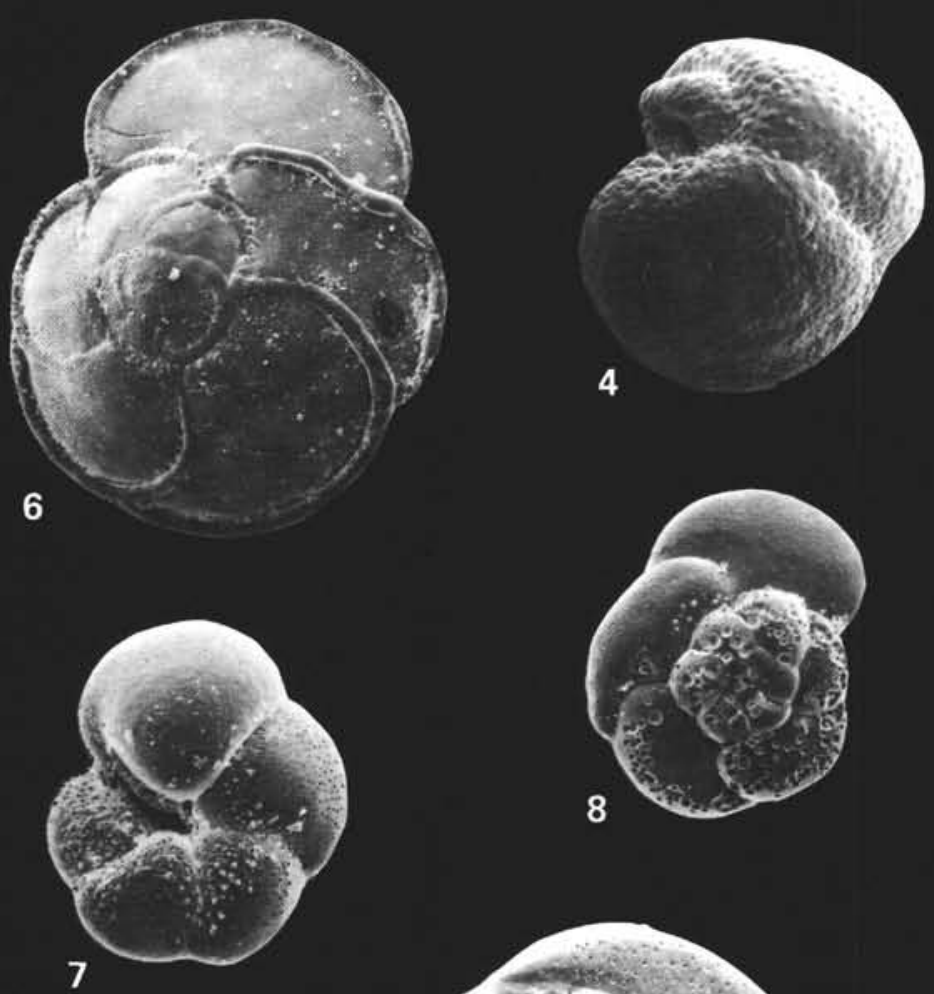

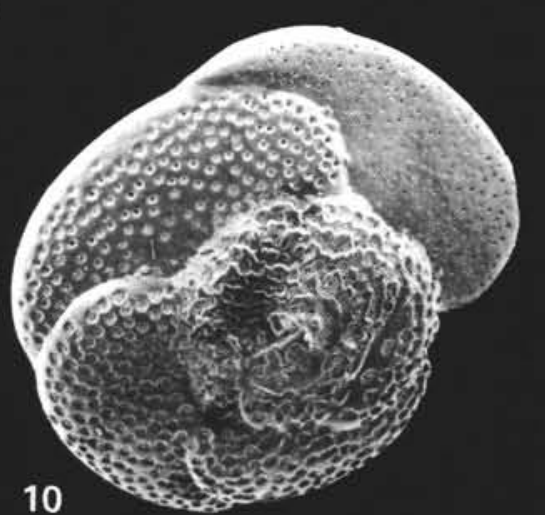

Plate 6. (Specimens magnified $\times 80$ unless otherwise indicated.) 1-2. Globorotalia hirsuta (d'Orbigny), Sample 517-1-1, 0-2.5 cm, (1) umbilical view, $\times 60$; (2) spiral view. 3-4. G. inflata (d’Orbigny), Sample 517-1-1, 0-2.5 cm, (3) umbilical view, (4) spiral view, $\times 100$. 5-6. G. menardii (d'Orbigny), Sample 517-1-1, 0-2.5 cm, $\times 60$, (5) umbilical view, (6) spiral view. 7-10. G. scitula (Brady), (7-8) Sample 517-1-1, 0-2.5 cm, $\times 120$, (7, umbilical view; 8, spiral view), (9-10) Sample 517-7,CC, (9, umbilical view; 10, spiral view). 

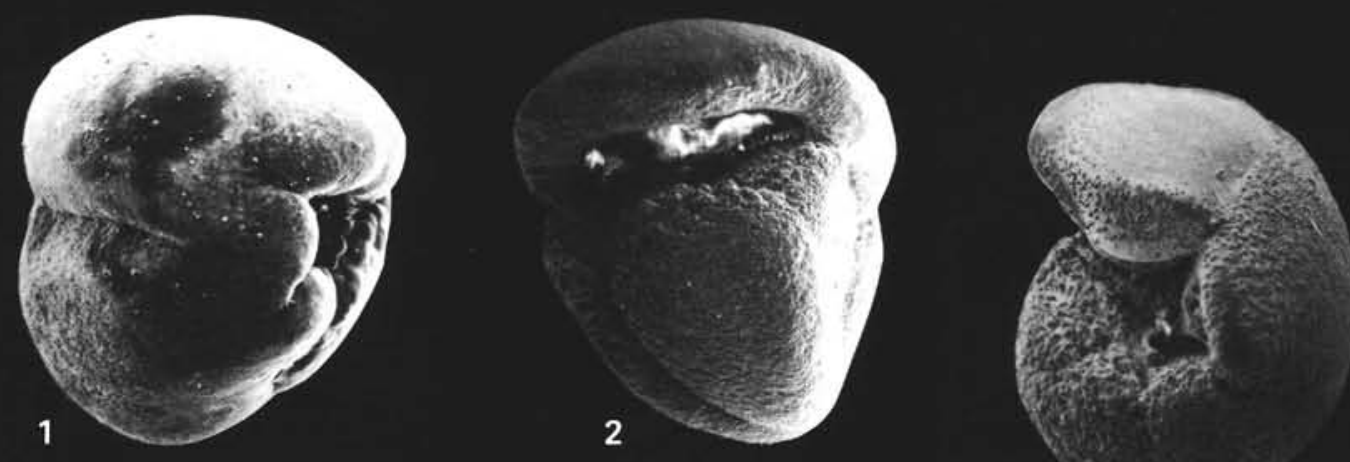

3
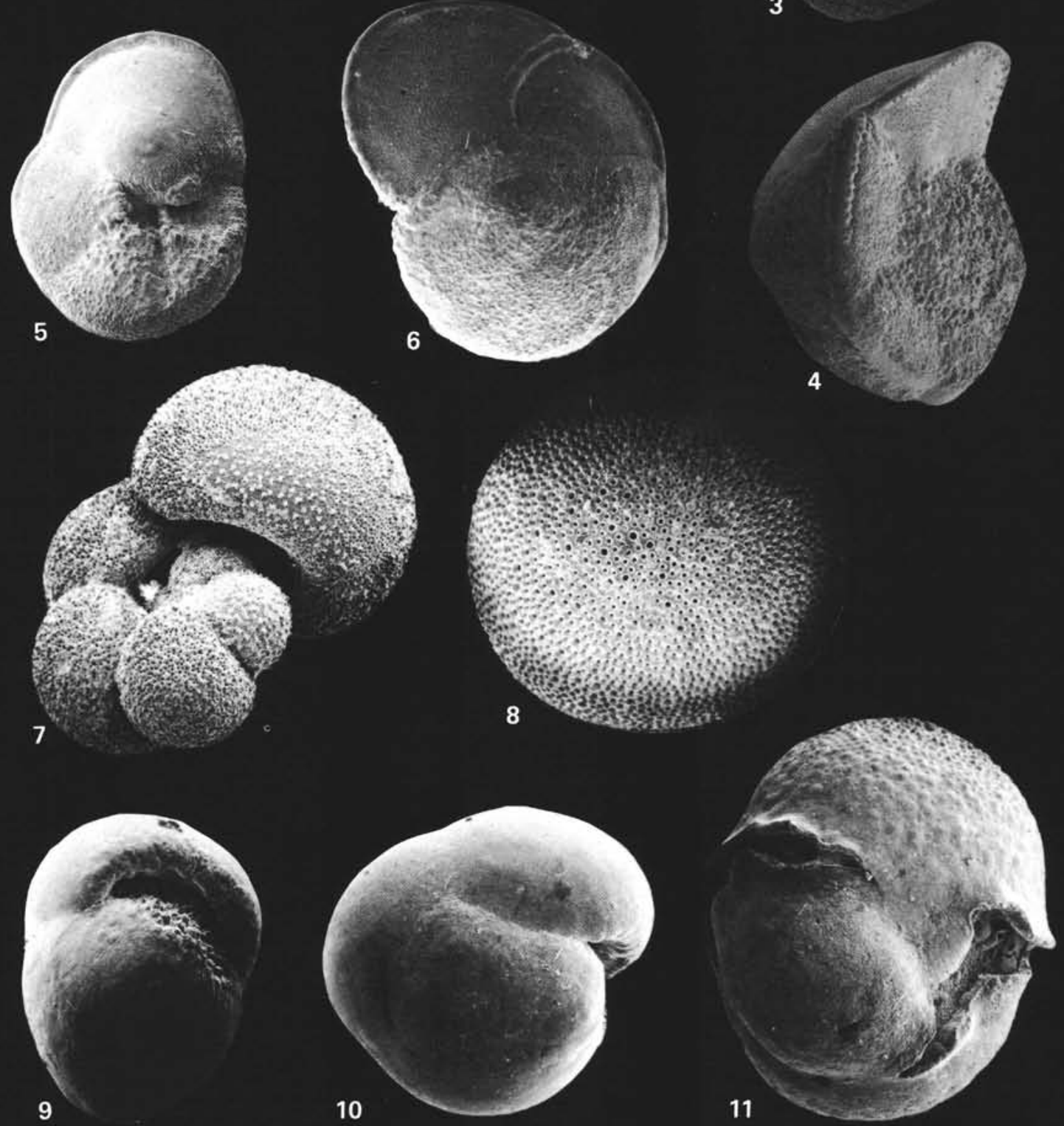

Plate 7. (Specimens magnified $\times 70$ unless otherwise indicated.) 1-2. Globorotalia triangula Theyer, Sample $517-7-3,50 \mathrm{~cm},(1) \mathrm{umbilical}$ view, (2) peripheral view, $\times 50$. 3-4. G. truncatulinoides (d'Orbigny), Sample 517-1-1, 0-2.5 cm, (3) umbilical view, $\times 50,(4)$ spiral view. 5-6. G. tumida (Brady), Sample 517-7-1, $50 \mathrm{~cm}, \times 50$, (5) umbilical view, (6) spiral view. 7. Hastigerina siphonifera d'Orbigny, Sample 517-4-2, 50 cm, peripheral view. 8. Orbulina universa d'Orbigny, Sample 517-1-1, 0-2.5 cm. 9-10. Pulleniatina obliquiloculata (Parker and Jones), Sample $517-4-2,50 \mathrm{~cm}$, (9) umbilical view, (10) spiral view. 11. Sphaeroidinella dehiscens (Parker and Jones), Sample 517-5-3, $10 \mathrm{~cm}$, spiral view. 